\title{
ADEQUATE PROTECTION AND THE AUTOMATIC STAY UNDER THE BANKRUPTCY CODE: EASING RESTRAINTS ON DEBTOR REORGANIZATION
}

Chapter 11 of the Bankruptcy Code ${ }^{1}$ is a rejection of economic Darwinism. It adopts the view that the conflicting interests of debtors and their creditors often can best be accommodated by rehabilitating financially distressed businesses rather than liquidating them. ${ }^{2}$ To encourage failing businesses to reorganize while rehabilitation is still possible, the Code grants a debtor ${ }^{3}$ a stay of its debts automatically on filing a chapter 11 bankruptcy petition." This "automatic stay" is designed to give debtors a "breathing spell" from the burdens of meeting their current obligations so that they can formulate an effective reorganization plan..$^{5}$ More importantly, by holding the debtor's secured

111 U.S.C. $\$ \S 1101-1174,1301-1330$ (Supp. V 1981). Cases filed after October 1, 1979, are governed by the Bankruptcy Reform Act of 1978, Pub. L. No. 95-598, 92 Stat. 2549 (codified at 11 U.S.C., in scattered sections of 28 U.S.C., and in scattered sections of other titles (Supp. V 1981)) (repealing the Bankruptcy Act of 1898, ch. 541, 30 Stat. 544 (codified as amended at 11 U.S.C. $\$ \S 1-1200$ (1976) (repealed 1979))). The jurisdictional provisions of the Act, 28 U.S.C. $\S \S 1471-1482$ (Supp. V 1981), were declared unconstitutional in Northern Pipeline Constr. Co. v. Marathon Pipe Line Co., 102 S. Ct. 2858 (1982) (broad grant of jurisdiction to bankruptcy judges a violation of article III of the Constitution).

I Cf. In re Chugiak Boat Works, Inc., 18 Bankr. 292, 298 (Bankr. D. Alaska 1982) (congressional policy underlying Code is to foster alternatives to liquidation). See generally Gordanier, The Indubitable Equivalent of Reclamation: Adequate Protection for Secured Creditors Under the Bankruptcy Code, 54 AM. BANKR. L.J. 299 (1980).

Actually, Congress recognized the advantages of debtor reorganization as early as 1934. See Rosenberg, Beyond Yale Express: Corporate Reorganizaton and the Secured Creditors Rights of Reclamation, 123 U. PA. L. REV. 509, 509 \& n.1 (1975) (discussing passage of $\S 77 \mathrm{~B}$ of the Bankruptcy Act, Act of June 7, 1934, ch. 424, § 1, 48 Stat. 912 (codified as amended at 11 U.S.C. § 616(7) (1976)) (repealed 1979)).

"The Code defines "debtor" as a "person or municipality concerning which a case under this title has been commenced." 11 U.S.C. $\S 101$ (12) (Supp. V 1981). As used in this Comment, the term refers to any individual, corporation, or business that has filed a petition for bankruptcy under the Code, or the trustee of the debtor's estate appointed under $\S 1104$.

- Id. § 362(a). Under the Code, voluntary bankruptcy cases are initiated by the debtor's filing a petition with the bankruptcy court. Id. § 301. Involuntary cases are also commenced by petition, but those petitions are filed by the debtor's creditors, who must meet the requirements of $\S 303$.

The stay also operates in straight liquidation bankruptcy where no reorganization plan is formed. This Comment, however, focuses on reorganization bankruptcies, primarily chapter 11 reorganizations. Id. $\S \S 1101-1174$. The provisions of chapter 11 governing the reorganization plan are $\$ \S 1121-1129$.

- "It gives the debtor a breathing spell from his creditors. It stops all collection efforts, all harassment, and all foreclosure actions. It permits the debtor to attempt a repayment or reorganization plan, or simply to be relieved of the financial pressures that drove him into bankruptcy." $S$. REP. NO. 989, 95th Cong., 2d Sess. 54, reprinted in 1978 U.S. CODE CONG. \& AD. NEWS 5787, 5840-41; H.R. REP. No. 595, 95th Cong., 2d Sess. 121, reprinted in 1978 U.S. CODE CONG. \& AD. NEWS 5963, 6296-97. 
creditors $^{6}$ at bay, the automatic stay enables the debtor-in-possession ${ }^{7}$ to retain and exploit its encumbered assets in implementing its reorganization plan. ${ }^{\mathbf{8}}$ Without these two protections, a debtor's chances for successful reorganization may be substantially reduced. Code also guarantees some degree of protection to creditors. One safeguard of their interests is found in the doctrine of "adequate protection." This Comment examines this poorly defined concept and suggests that, in order to allow debtors a realistic chance to reorganize-one of the Code's underlying goals-courts should feel less constrained by the overly restrictive constitutional and policy considerations currently embraced in recent decisions. Part I examines the origin and current interpretation of the adequate protection concept in depth, discussing the practical and theoretical problems assocciated with it. Part II suggests an alternative definition of adequate protection consistent with creditors' constitutional rights and with the policy of debtor rehabilitation promoted by the Code.

\section{Adequate Protection: Development of the Current Standard}

\section{A. When the Adequate Protection Requirement Must Be Met: Lifting the Automatic Stay}

The automatic stay granted a debtor under chapter 11 is often essential to its successful formulation of a reorganization plan. If the loss of essential encumbered assets is added to the cash-flow problems

- As used in this Comment, "secured creditor" refers to any creditor holding an allowed secured claim against the debtor's estate. The Code defines "creditor" to include any "entity that has a claim against the debtor that arose at the time of or before the order for relief concerning the debtor." 11 U.S.C. $\S 101(9)$ (A) (Supp. V 1981). A "claim" is a "right to payment." Id. $\S 101(4)(\mathrm{A})$. A claim is secured under the Code if it is "allowed" under $\S 502$ and is secured by a lien on property in which the debtor's estate has an "interest." Id. § 506(a). It is secured only to the "extent of the value of such creditor's interest in the estate's interest in such property . . . and is an unsecured claim to the extent that the value of such creditor's interest . . . is less than the amount of such allowed claim." Id. § 506(a). For example, if a creditor has a \$1,000 mortgage on property of the debtor's estate but the property is worth only $\$ 800$ on the date the petition is filed, the creditor's claim is secured for only $\$ 800$ and the creditor has an unsecured claim of $\$ 200$. In essence, the creditor has a secured claim in the amount of the debt owed or the value of its collateral, whichever is less.

711 U.S.C. \& 1107(a) (Supp. V 1981) states:

Subject to any limitations on a trustee under this chapter, and to such limitations or conditions as the court prescribes, a debtor in possession shall have all the rights, other than the right to compensation under section 330 of this title, and powers, and shall perform all the functions and duties, except the duties specified in section 1106(a)(2), (3), and (4) of this title, of a trustee serving in a case under this chapter.

The terms debtor and debtor-in-possession are used interchangeably in this Comment.

See id. § 362(a)(4). 
inevitably accompanying bankruptcy, the debtor may barely have the means to stay in business. ${ }^{9}$ Once the automatic stay is in place, the debtor-in-possession can use, sell, or lease these encumbered assets as long as such action is in the ordinary course of business. ${ }^{10}$ In addition, the automatic stay provides the debtor with a procedure for obtaining credit. ${ }^{11}$

For a period of 120 days after the automatic stay is imposed, the debtor has the exclusive right to file a chapter 11 reorganization "plan."12 If the debtor misses this deadline, or if a trustee has been appointed, however, any party in interest may file a plan, including the trustee, the debtor, a creditor, or the creditors' committee. ${ }^{13}$

Once filed, the plan must be accepted by the interested parties. The Code provides an elaborate set of guidelines governing who may vote on the plans and what majorities are needed for approval. ${ }^{14}$ Ultimately, the bankruptcy court holds a confirmation hearing. ${ }^{18}$ The plan may be confirmed at this hearing under a procedure known as the "cram down" despite the objections of one or more classes of creditors. ${ }^{16}$ Generally, the effect of a confirmation is equivalent to that of a discharge. ${ }^{17}$

This discussion of reorganization proceedings has assumed that no secured creditor objects to the debtor's retention of collateral prior to the confirmation hearing. Under section 362 of the Code, a secured creditor may obtain, after a hearing, a lifting or modification of the stay "for cause, including the lack of adequate protection" of the creditor's interest in the debtor's property. ${ }^{18}$ The burden is on the debtor to show that the creditors' properties are adequately protected. ${ }^{19}$ If the stay is

- See Gordanier, supra note 2, at 320.

10 See 11 U.S.C. § 363 (Supp. V 1981).

11 See id. $\S 364$.

13 Id. \& 1121(b).

13 Id. $\S 1121$ (c). These parties may also file a plan if the debtor's plan has not been accepted by all classes of creditors within 180 days after the automatic stay is imposed. Id. $\S 1121(b)(3)$.

${ }^{14}$ Id. § 1126(a), (c).

18 Id. § 1128.

10 Id. $\S 1129(b)(1)$. For a general discussion of this procedure, see Klee, All You Ever Wanted to Know About Cram Down Under the New Bankruptcy Code, 53 AM. BANKR. L.J. 133 (1979).

${ }^{17}$ See 11 U.S.C. \& 1141(d) (Supp. V 1981).

1* On request of a party in interest and after notice and a hearing, the court shall grant relief from the stay provided under subsection (a) of this section, such as by terminating, annulling, modifying, or conditioning such stay-

(1) for cause, including the lack of adequate protection of an interest in property of such party in interest. . . .

11 U.S.C. § 362(d) (Supp. V 1981). The Code specifically allows the debtor to use encumbered property, including cash collateral, and incur debts secured by property that is already encumbered, providing that secured creditors' interests are adequately protected. Id. $\S \S 363,364$.

10 Id. § $362(\mathrm{~g})$. Usually it is the debtor, not the bankruptcy court, that must formulate and 
lifted, the secured creditor may completely foreclose on its collateral, perhaps seriously impeding the debtor's reorganization. Thus "adequate protection" is a concept crucial to the effectiveness and viability of reorganization efforts prior to the confirmation hearing.

\section{B. Adequate Protection: The Source of the Concept}

The Code never explicitly defines the term "adequate protection." The Code's legislative history, ${ }^{20}$ however, makes it clear that the concept derives from two sources: the secured creditors' contractual rights to receive the benefit of their bargain, and their constitutional rights in their collateral as property protected by the fifth amendment's due process $^{21}$ and takings clauses. ${ }^{22}$ Thus, the idea of "adequate protection" brings the secured creditor's contractual and property rights into direct conflict with the policy favoring debtor rehabilitation: The debtor claims rights under federal bankruptcy law to retain the assets it needs to reorganize, and the secured creditor demands protection of its state contractual rights and constitutional property rights to reclaim those assets through foreclosure. In resolving this conflict, many bankruptcy courts appear to give undue deference to the secured creditors' rights, leading them to impose standards of adequate protection that seriously impede and often arrest the debtor's reorganization.

\section{The Emerging Case Law}

Congress's failure to define "adequate protection" precisely may well have been a deliberate effort to provide the courts with an "open-

offer methods of adequate protection. The bankruptcy court's function is to determine whether the offered method is adequate. See 11 U.S.C. $\$ 362$ (d) (Supp. V 1981); S. REP. No. 989, supra note 5, at 49, 1978 U.S. CODE CONG. \& AD. NEWS at 5835; H.R. REP. No. 595, supra note 5, at 338, 1978 U.S. CODE CONG. \& AD. NEWS at 6295. But see In re Pleasant Valley, Inc., 6 Bankr. 13, 17-18 (Bankr. D. Nev. 1980), cited in In re Alyucan Interstate Corp., 12 Bankr. 803, 809 n.12 (Bankr. D. Utah 1981) as an example of a case in which the bankruptcy judge took a more active role.

so See S. REP. NO. 989, supra note 5, at 49, 53, 1978 U.S. CODE CONG. \& AD. NEWS at 5835,5839 ("This section and the concept of adequate protection are based as much on policy grounds as on constitutional grounds. Secured creditors should not be deprived of the benefit of their bargain."); see also H.R. REP. NO. 595, supra note 5, at 339, 1978 U.S. CODE CONG. \& AD. NEWS at 6295.

${ }_{21}$ U.S. CONST. amend. V, cl. 3 (no person shall be "deprived of . . . property, without due process of law"). Security interests give the holder property rights in the collateral. See Louisville Joint Stock Land Bank v. Radford, 295 U.S. 555 (1935).

32 Id. at cl. 4 ("nor shall private property be taken for public use, without just compensation"); see also In re Family Invs., Inc., 8 Bankr. 572, 576 (Bankr. W.D. Ky. 1981). Secured creditors' contractual rights are not constitutionally protected against impairment by the federal government. Only the states are bound by the contract clause. U.S. CONST. art. I, $\S 10$ ("No state shall .. . pass any ... . law impairing the obligation of contracts"). See Continental 111. Nat'l Bank \& Trust Co. v. Chicago R.I. \& Pac. Ry., 294 U.S. 648 (1935). 
textured, pliant, and versatile" concept. ${ }^{23}$ Such judicial flexibility is desirable because the court must accommodate a wide range of competing interests in a reorganization attempt. ${ }^{24}$ The court should accord weight, not only to the interests of the debtor and creditor, but also to the interest of the debtor's employees in keeping their jobs; that of the public in generating tax revenues and avoiding increased unemployment and welfare payments; that of consumers in maintaining competition in the debtor's industry; and that of the debtor's suppliers in receiving a reasonable return on their unsecured claims. ${ }^{25}$

\section{The Code Provisions}

The Code and its legislative history do provide some guidance as to the general "contours of the concept" of adequate protection. ${ }^{26} \mathrm{Sec}$ tion 361 lists three methods of providing adequate protection for creditors seeking relief from the automatic stay. ${ }^{27}$ The first method is to require the debtor to make periodic cash payments to the secured creditor equal to any decrease in the value of that creditor's interest in the debtor's property caused by the stay. ${ }^{28}$ The second method is to grant the secured creditor an additional or replacement lien on other, nonencumbered assets to the extent that the stay causes the value of the original secured asset to decrease. ${ }^{29}$ This method is similar to the first,

23 In re Alyucan Interstate Corp., 12 Bankr. 803, 805 (Bankr. D. Utah 1981) ("Adequate protection is not defined in the Code. This omission was probably deliberate."). See also In re Cooper, 22 Bankr. 718, 720 n.3 (Bankr. E.D. Pa. 1982).

"It In re Alyucan Interstate Corp., 12 Bankr. at 805.

1s See Rosenberg, supra note 2, at 539-42. Rosenberg refers to these interests as the public interest in successful reorganization. See also Webster, Collateral Control Decisions in Chapter Cases: Clear Rules v. Judicial Discretion, 51 AM. BANKR. L.J. 197, 203 (1977).

16 See H.R. REP. No. 595, supra note 5, at 338, 1978 U.S. CODE CONG. \& AD. NEWS at 6295.

2711 U.S.C. § 361 (Supp. V 1981). See In re Paradise Boat Leasing Corp., 5 Bankr. 822, 824 (D. St. Thomas \& St. John, V.I. 1980); 2 COLliER ON BANKRUPTCY I 362.07, at 362-48 (methods in $\S 361$ merely illustrative) (L. King 15th ed. 1982) [hereinafter cited as CoLLIER]. The methods listed in $\S 361$ also apply to the adequate protection requirements of $\S \S 363(\mathrm{e})$ (permitting the trustee to use, sell or lease encumbered property, including cash collateral) and 364(d)(1)(B) (permitting the trustee to incur secured debts).

28 This method is derived from In re Bermec, 445 F.2d 367 (2d Cir. 1971), a case decided under the old Bankruptcy Act, ch. 541, 30 Stat. 544 (codified as amended at 11 U.S.C., in scattered sections of 28 U.S.C., and in scattered sections of other titles (1976) (repealed 1979)). See S. REP. No. 989, supra note 5, at 54, 1978 U.S. CODE CONG. \& AD. NEWS at 5840. In Bermec, a secured creditor requested that the stay be lifted because the debtor's continued use of its encumbered trucks was rapidly depreciating their value. The court rejected the creditor's request, but required the debtor to preserve the status quo by making cash payments to the secured creditor equal to the amount of the depreciation. The court acknowledged the secured creditor's fear that should the reorganization fail, its lien would become worthless, but noted that the secured creditor's right to the value of its collateral must be balanced against "the Congressional mandate" to encourage business reorganizations. 445 F.2d at 369.

20 11 U.S.C. \& 361(2) (Supp. V 1981). 
but it gives the cash-poor debtor a way of meeting the adequate protection requirement. The third method provides adequate protection by "granting such other relief . . . as will result in the realization by [the secured creditor] of the indubitable equivalent of [its] interest" in the debtor's property. ${ }^{30}$

One commentator has criticized the first method for the "obvious" reason that debtors filing under chapter 11 often have serious cash-flow problems, and periodic payments may render reorganization virtually impossible. ${ }^{31}$ The same author has noted that the second method may also prove infeasible: because the Uniform Commercial Code makes perfecting security agreements realitively easy, a debtor resorting to chapter 11 will probably not have sufficient unencumbered assets to support replacement liens. ${ }^{32}$ Thus, the debtor's only realistic alternative is the "indubitable equivalent" standard, an umbrella provision incorporated into section 361 to give the bankruptcy courts added flexibility. ${ }^{3 s}$

Instead of taking advantage of this flexibility to approach reorganization cases creatively, several bankruptcy courts have used the indubitable equivalent standard in a way that may seriously hamper the

so Id. § 361(3).

s1 See Gordanier, supra note 2, at 313 .

32 Id. at 314.

38 H.R. REP. NO. 595, supra note 5, at 340, 1978 U.S. CODE CONG. \& AD. NEWS at 6296. The term "indubitable equivalent" was actually a late change in the text of $\S 361$. As originally introduced in the House, the Bankruptcy Act of 1978 provided four methods of adequate protection: periodic payments, replacement liens, an administrative priority, and such other relief as would result in the creditor realizing the value of its allowed secured claim. H.R. 8200, 95th Cong.,1st Sess. § 361, 123 CONG. REC. 35,649 (1978). See also H.R. REP. No. 595, supra note 5, at 339, 1978 U.S. CODE CONG. \& AD. NEWS at 6295 (methods "neither exclusive nor exhaustive"). Because deliberations in the House bogged down in debate over the article III jurisdiction of the bankruptcy courts, see Northern Pipeline Constr. Co. v. Marathon Pipe Line Co., 102 S. Ct. 2858, 2879-80 (1982), the bill's proponents introduced a similar version in the Senate. S. 2266, 95th Cong., 1st Sess. (1977). The Senate provided for two, exclusive methods of adequate protection in its version of $\S 361$ : periodic payments and replacement liens. See S. REP. No. 989, supra note 5, at 54, 1978 U.S. CODE CONG. \& AD. NEWS at 5840. During hearings on S. 2266, the Senate was urged to give the trustee "maximum flexibility in devising a sufficient protection." Bankruptcy Reform Act of 1978: Hearings on S. 2266 and H.R. 8200 Before the Subcomm. on Improvements in Judicial Machinery of the Senate Comm. on the Judiciary, 95th Cong., 1st Sess. 963 (1977) [hereinafter cited as Hearings] (statement of the Federal Home Loan Bank Board). The Federal Home Loan Bank Board suggested that the Senate adopt a third, catch-all method "to grant such other relief as would result in the claimant realizing the full value of its interest." Id. After a great deal of parliamentary shuffing, $\S 361$ of the Bankruptcy Reform Act of 1978, as passed on October 6, 1978, see 124 CONG. REG. 34,143-44 (1978), incorporated the first two methods of both bills (periodic payments and replacement liens), eliminated the administrative priority method as being too uncertain to be meaningful, and reworded the House bill's fourth method from "realization . . . of the value" to "realization ... of the indubitable equivalent of" the secured creditor's property interest. See id. at 32,395 (remarks of Rep. Edwards, House sponsor of H.R. 8200). For an interesting historical and political insight into the legislative process of enacting the Bankruptcy Reform Act of 1978, see Klee, Legislative History of the New Bankruptcy Code, 28 DEPAUL. L. REV. 941 (1979), reprinted in 54 AM. BANKR. L.J. 275 (1980). 
debtor's capacity to reorganize successfully. ${ }^{34}$ Much of the problem stems from the courts' reliance on a 1935 case $^{38}$ interpreting "indubitable equivalence" to mean that the creditor must be "completely compensated."

\section{The "Completely Compensatory" Standard of Indubitable Equivalence}

The phrase "indubitable equivalence" was originated in 1935 by Judge Learned Hand in In re Murel Holding Corp. ${ }^{36}$ The issue in Murel was whether a debtor's reorganization plan provided "adequate protection" for a secured creditor's lien. ${ }^{37}$ Under its plan, the debtor in Murel offered to pay the secured creditor five-and-a-half percent interest on its debt if the secured creditor would suspend the debt's $\$ 9,000$ annual amortization payments for ten years. ${ }^{38}$ Hand rejected the argument that this offer adequately protected the secured creditor's rights under the lien.

In construing so vague a grant, we are to remember not only the underlying purposes of the section, but the constitutional limitations to which it must conform. It is plain that "adequate protection" must be completely compensatory; and that payment ten years hence is not generally the equivalent of payment now . . . . We see no reason to suppose that the statute was intended to deprive [the secured creditor] of that in the interest of junior holders, unless by a substitute of the most indubitable equivalence. ${ }^{\text {s9 }}$

st See, e.g., In re Thomas Parker Enters., Inc., 10 Bankr. 783, 789-90 (Bankr. D. Conn. 1981); In re Caulk, 9 Bankr. 242, 244 (Bankr. E.D. Pa. 1981); In re Curtis, 9 Bankr. 110, 112 (Bankr. E.D. Pa. 1981) (debtor met indubitable equivalent requirement because his equity cushion was "sufficiently large"); In re Anchorage Boat Sales, Inc., 4 Bankr. 635, 643 (Bankr. E.D.N.Y. 1980); In re Antilles Yachting, Inc., 4 Bankr. 470, 472 (Bankr. D. St. Thomas \& St. John, V.I. 1980); In re Cartwright Land Assocs., 3 Bankr. 277, 280 (Bankr. S.D.N.Y. 1980) (refusing to confirm plan that failed to provide for payment in full or its indubitable equivalent); In $r$ Paradise Boat Leasing Corp., 2 Bankr. 482, 484 (Bankr. D. St. Thomas \& St. John, V.I. 1979) ("Under this language of the Code, even if the Debtor needs the secured property for reorganization he may not use it unless there is no doubt that what the secured creditor is to get, is equal in all particulars to the rights the creditor may have to surrender."), remanded, 5 Bankr. 822 (D. St. Thomas \& St. John, V.I. 1980). But see In re Waynesboro Hotel Co., 19 Bankr. 561, 562 (Bankr. M.D. Pa. 1982) (even though creditor lacked adequate protection, court found sufficient interim protection to maintain stay); In re Prime, 15 Bankr. 216, 219 (Bankr. W.D. Mo. 1981) (more rigorous accounting methods provide adequate protection for use of cash collateral); In re Markim, Inc., 15 Bankr. 56, 59 (Bankr. E.D. Pa. 1981) (monthly payments and increased efficiency provide adequate protection for use of cash collateral).

2s In re Murel Holding Corp., 75 F.2d 941, 942 (2d Cir. 1935).

s. Id.

37 Id.

28 Id.

* Id. (emphasis added). 
Several bankruptcy courts have cited this passage in the Murel opinion as the controlling definition of adequate protection under sections 361 and 362 of the Bankruptcy Code. ${ }^{40}$ These courts have held that the debtor's offered protection must be completely compensatory, "equal in all particulars to rights the creditor may have to surrender," 11 and never less than the payments agreed to in the original debt instrument. ${ }^{42}$ Reasoning that the secured creditor gives up the right to foreclose on the collateral and reinvest the proceeds from a foreclosure sale, these courts have concluded that the indubitable equivalent of that right is what the secured creditor could have received "if he had in his hands today an amount equal to the value of the collateral and was able to reinvest this amount in a way which would produce a return on his investment."43 One court held, for example, that a debtor's offer to make periodic payments at the legal rate of interest of nine percent was not the indubitable equivalent of its secured creditor's claim because the then-current rate of return on investments was twenty percent. ${ }^{44}$

The "completely compensatory".standard has also been applied in cases in which the debtor has offered an "equity cushion" as adequate protection..$^{45}$ An equity cushion is the amount by which the value of the collateral exceeds the amount of the indebtedness it secures. If, for example, $X$ 's $\$ 100$ debt to $Y$ is secured by property valued at $\$ 150, Y$ has a fully secured claim for $\$ 100$ and a $\$ 50$ equity cushion ( $\$ 150$ minus $\$ 100$ equals $\$ 50$ ). Even if the value of the collateral decreases to $\$ 100, Y$ still has a fully secured $\$ 100$ claim because the equity cushion absorbs the $\$ 50$ loss. $^{48}$

10 See cases cited supra note 34.

11 Paradise Boat Leasing, 2 Bankr. at 484.

43 Id. at 483.

t3 In re Anchorage Boat Sales, Inc., 4 Bankr. 635, 643 (Bankr. E.D.N.Y. 1980). 1980).

44 In re Antilles Yachting, Inc., 4 Bankr. 470, 472 (Bankr. D. St. Thomas \& St. John, V.I.

ts See e.g., In re High Sky, Inc., 15 Bankr. 332 (Bankr. M.D. Pa. 1981); In re Pannell, 12 Bankr. 51 (Bankr. E.D. Pa. 1981); In re Stuart Motel, Inc., 8 Bankr. 50 (Bankr. S.D. Fla. 1980); In re Tucker, 5 Bankr. 180 (Bankr. S.D.N.Y. 1980); In re Lake Tahoe Land Co., 5 Bankr. 34 (Bankr. D. Nev. 1980); In re Pitts, 2 Bankr. 476 (Bankr. C.D. Cal. 1979).

to The example becomes complicated when more than one creditor holds a security interest in the same collateral. To illustrate the problem, using the example in the text, suppose $A$ has a $\$ 25$ and $B$ a $\$ 50$ security interest in the same collateral in which $Y$ has a $\$ 100$ security interest. Further suppose that $A$ 's lien is junior to $Y$ 's lien and $B$ 's lien is junior to $A$ 's (i.e., $Y$ 's lien has priority over $A$ 's, and $A$ 's has priority over $B$ 's). The collateral is valued at $\$ 150$. Under $\$ 506(a)$ of the Code, 11 U.S.C. $\$ 506$ (a) (Supp. V 1981), $Y$ has a secured claim for $\$ 100$ and a $\$ 50$ equity cushion; $A$ has a secured claim for $\$ 25$ and a $\$ 25$ equity cushion; and $B$ has a secured claim for $\$ 25$ with no equity cushion and an unsecured claim for \$25. Any erosion of $Y$ 's equity cushion caused by a diminution in the collateral's value also adversely affects $A$ 's equity cushion and $B$ 's secured status. If the collateral value dips to $\$ 100$, only $Y$ remains fully secured, while $A$ 's and $B$ 's claims are rendered worthless.

Some courts hold that the equity cushion of an individual secured creditor, such as $Y$ in the above illustration, is adequate protection of that particular secured creditor's allowed secured 
The equity cushion is widely accepted as a method of providing adequate protection. ${ }^{47}$ Courts disagree, however, on the extent to which the equity cushion does afford adequate protection, or whether the equity cushion itself must be adequately protected to some degree. Some courts simply hold that any equity cushion constitutes adequate protection. The "completely compensatory" courts, however, take the position that an equity cushion is adequate protection only if the cushion is as large or larger than the equity cushion that the parties bargained for in the security agreement or that existed when the lien was created. ${ }^{48}$ Thus, in In re Lake Tahoe Land Company, ${ }^{49}$ the court held that to adequately protect a commercial lender who has extended credit for the purchase of undeveloped real property, the debtor must show an equity cushion equaling forty to fifty percent of the market value of the land because "experienced lender[s] will not loan more than $50 \%$ to $60 \%$ of appraised value of raw land."

claim. See, e.g., In re Pleasant Valley, Inc., 6 Bankr. 13 (Bankr. D. Nev. 1980). Other courts, however, hold that the adequate protection standard is met only if a net equity cushion remains after all the secured creditors' claims are subtracted from the collateral's value. In the absence of a net equity cushion the debtor must make "meaningful provisions for not worsening the position of creditors in general." First Conn. Small Business Inv. Co. v. Ruark, 7 Bankr. 46, 49 (Bankr. D. Conn. 1980) (emphasis added). See also In re American Properties, 8 Bankr. 68 (Bankr. D. Kan. 1980) (debtor must pay junior creditors an amount equal to the accruing interest on the senior creditor's debt in order to prevent erosion of the senior secured creditor's equity cushion-in effect, the debtor is required to make double interest payments on his senior debt).

47 It has been dubbed "the classic form of protection for a secured debt." In re Curtis, 9 Bankr. 110, 112 (Bankr. E.D. Pa. 1981).

48 See cases cited supra note 45; see also Massari, Adequate Protection Under the Bankruptcy Reform Act, in ANNUAL SURVEY OF BANKRUPTCY LAW 171 (1979) (maintaining that the adequate protection standard depends on the original collateral-debt ratio provided for in the security instrument). But see In re Alyucan Interstate Corp., 12 Bankr. 803, 806 (Bankr. D. Utah 1981) ("interest in property entitled to protection" under $\S 362$ of the Code not measured by amount of debt).

4D 5 Bankr. 34 (Bankr. D. Nev. 1980).

so Id. at $37 \&$ n.9. Other courts have required that the equity cushion be maintained at a level that accounts for interest and depreciation accumulating against the collateral in the immediate future. They reason that the stay should be lifted when the secured creditor can no longer realize the full amount of its allowed secured claim from the value of the collateral. Under the Uniform Commercial Code, a secured creditor is entitled to a "commercially reasonable disposition" of its collateral and should be given a reasonable time to get the best price. See U.C.C. § 9504(3) (1978). Because the equity cushion continues to be eroded by the accrual of interest and by depreciation while the secured creditor is seeking a buyer, it must be large enough to enable the creditor to receive the full amount of its allowed secured claim if it sells the collateral on the final day of the "commercially reasonable" period. See, e.g., In re Lee, 11 Bankr. 84 (Bankr. E.D. Pa. 1981); In re Orlando Coals, Inc., 6 Bankr. 721, 723-24 (Bankr. S.D.W. Va. 1980); In re 5-Leaf Clover Corp., 6 Bankr. 463, 466-67 (Bankr. S.D.W. Va. 1980) (allowing a 60-day period to assure best disposition of collateral).

For examples of courts holding that any equity cushion constitutes adequate protection, see, c.g., In re Nixon Machinery Co., 9 Bankr. 316 (Bankr. E.D. Tenn. 1981); In re Family Invs., Inc, 8 Bankr. 572 (Bankr. W.D. Ky. 1981) (equity cushion generally preserves benefit of bargain); In re Vincent, 7 Bankr. 866 (Bankr. M.D. Fla. 1980); In re Shockley Forest Indus., Inc., 5 Bankr. 160 (Bankr. N.D. Ga. 1980); In re Rogers Dev. Corp., 2 Bankr. 679, 683 (Bankr. E.D. Va. 1980); In re McAloon, 1 Bankr. 766 (Bankr. E.D. Pa. 1980). 
The completely compensatory/indubitable-equivalent standard of adequate protection may be appealing when viewed in the abstract. It makes eminent sense that a party should receive the full benefit of its bargain. In addition, the secured creditor's property rights in the collateral are constitutionally protected; ${ }^{51}$ as Learned Hand stated in Murel, courts must construe the bankruptcy statutes in light of those constitutional limitations. ${ }^{62} \mathrm{~A}$ strict definition of adequate protection as "completely compensatory" may, however, sabotage the reorganization process. ${ }^{\text {s3 }}$

\section{Problems with the "Completely Compensatory" Standard}

Making "adequate protection" synonymous with "complete compensation" may cause severe difficulties for debtors. For example, requiring a debtor to make payments to all of its secured creditors at the current rate of interest ${ }^{64}$ may drain its available cash. Businesses that file reorganization petitions often have very little cash on hand ${ }^{55}$ and hope that the brief respite provided by chapter 11 will allow them to solve their financial difficulties by restructuring their debt. ${ }^{56}$ If the debtor is unable to meet the required adequate protection payments, it will lose valuable assets necessary to its reorganization. Even if the debtor has equity in the creditor's collateral, it is unable to exploit that equity to generate fresh working capital because "completely compensatory" courts require that the equity cushion must be adequately protected as well. ${ }^{.7}$ Thus, court-imposed interest payments may undermine the "breathing spell" that the automatic stay was meant to provide. ${ }^{\mathbf{8}}$

s1 See supra notes 21-22 and accompanying text.

8275 F.2d at 941.

ss See In re Xinde Int'l, Inc., 13 Bankr. 212, 215 (Bankr. D. Mass. 1981); cf. Rosenberg, supra note 2, at 525-36 (describing secured creditors as "saboteurs" in their efforts to protect their claims).

54 See supra note 44 and accompanying text.

bs See Gordanier, supra note 2, at 320 (quoting Hughes, "Wavering Betweeen the Profit and the Loss": Operating a Business During Reorganization Under Chapter 11 of the New Bankruptcy Code, 54 AM. BANKR. L.J. 45, 72-73, 75 (1980)).

se The issue of adequate protection arises only if the court determines that the debtor has equity in the collateral or that the collateral is an asset necessary to the debtor's effective reorganization. In the absence of such findings, the stay is lifted and the creditors do not need the court's protection because they can protect themselves by foreclosing. See 11 U.S.C. $\S 362$ (d)(2) (Supp. V 1981); see also In re Caulk, 9 Bankr. 242, 243-44 (Bankr. E.D. Pa. 1981). Before a court can hold that an asset is necessary to the effective reorganization of the debtor's business, it must determine that a successful reorganization is in fact possible. See, e.g., In re Martin, 19 Bankr. 496, 498 (Bankr. E.D. Pa. 1982); In re Clark Technical Assocs., Ltd., 9 Bankr. 738, 740 (Bankr. D. Conn. 1981); In re Terra Mar Assocs., 3 Bankr. 462, 465-66 (Bankr. D. Conn. 1980). For an analysis of the "necessary to an effective reorganization" requirement, see In re Koopmans, 22 Bankr. 395, 396-408 (Bankr. D. Utah 1982).

${ }^{B 7}$ See supra notes $45-50$ and accompanying text.

Be See supra note 5 . 
Another function of the automatic stay that may be thwarted by the "completely compensatory" rationale is that of providing an incentive for creditors to reach a voluntary settlement of their claims against the debtor's estate. Ideally, the reorganization is accomplished through such a "workout." If the standard for adequate protection is "completely compensatory," the secured creditor has little to lose by directing its energies toward seeking adequate protection rather than formulating a reorganization plan with the debtor and other creditors: the secured creditor that is able to obtain this level of protection at the automatic-stay stage will be completely compensated no matter what happens to the debtor. If the debtor's reorganization fails and its business is liquidated, any secured creditor that has petitioned for adequate protection is entitled to an administrative priority for its claim if the protection it received proves inadequate. ${ }^{60}$ The amount of the priority claim is equal to the amount of the inadequacy, ${ }^{61}$ which, under the cases that rely on Murel, ${ }^{62}$ is anything short of complete compensation. Risk-averse secured creditors are therefore more likely to press for completely compensatory adequate protection than to compromise their claims in a voluntary plan in the hope of being repaid from the profits of the reorganized business.

The "completely compensatory" standard of adequate protection may also hurt creditors as well as debtors. A major purpose of the automatic stay is to protect creditors from one another.

Without [the stay], certain creditors would be able to pursue their own remedies against the debtor's property. Those who acted first would obtain payment of the claims in preference to and to the detriment of other creditors. Bankruptcy is designed to provide an orderly liquidation procedure under which all creditors are treated equally. A race of diligence by creditors for the debtor's assets prevents that. ${ }^{63}$

Under the "completely compensatory" standard, however, the adequate

89 See In re Alyucan Interstate Corp., 12 Bankr. 803, 806 (Bankr. D. Utah 1981). The success of the Bankruptcy Act of 1898 is often attributed to the strong bargaining position it gave the debtor. See Gordanier, supra note 2, at 32; see also Hearings, supra note 33, at 821 (statement of L.E. Cree III). Under the old Act, the debtor could force the cooperation of its creditors by failing to produce a favorable reorganization plan. Gordanier, supra, at 32l. Under the present Code, however, the requirement that secured creditors receive adequate protection, and the fact that any interested party may be able to proffer a reorganization plan for the debtor, see supra note 13 and accompanying text, have deprived the debtor of leverage in the reorganization process.

so 11 U.S.C. $\$ \S 503(\mathrm{~b})(1)(A), 507$ (b) (Supp. V 1981).

${ }^{1}$ Id. See 124 CONG. REC. 32,395 (1978) (statement of Rep. Edwards, House sponsor of H.R. 8200, which became the Bankruptcy Code).

${ }_{62}$ See cases listed supra note 34 .

os H.R. REP. NO. 595, supra note 5, at 340, 1978 U.S. CODE CONG. \& AD. NEwS at 6297. 
protection hearing may reintroduce into bankruptcy proceedings the "race of diligence" that the automatic stay was designed to prevent. Secured creditors, naturally a self-interested lot, generally prefer to receive cash in satisfaction of their debts rather than to wait and seek recovery from a defaulting debtor through foreclosure on their collateral. ${ }^{64}$ They also realize that a debtor who must resort to reorganization has limited cash resources with which to make completely compensatory adequate protection payments. Rather than risking coming away empty-handed, creditors may scramble to be first to request adequate protection. Such a race of diligence not only might circumvent established priority rules, ${ }^{65}$ but it also could require the debtor to begin adequate protection payments very early in the reorganization proceedings, further threatening the efficacy of the promised breathing spell.

Moreover, if courts provide secured creditors with payments above the amount necessary to compensate them for economic depreciation of their collateral, the status quo between secured and unsecured creditors may be disrupted. In a straight liquidation bankruptcy, secured creditors are paid from the proceeds of their collateral, up to the amount of the debt or the value of the collateral, whichever is less. ${ }^{b 6}$ Unsecured creditors receive a ratable share of any unencumbered value remaining in the debtor's estate. ${ }^{67}$ If, during the automatic stay, secured creditors are receiving payment from unencumbered liquid assets or are accumulating claims against their equity cushions, little or no unsecured value will be left in the debtor's estate to pay unsecured creditors should the debtor's reorganization fail. The problem is compounded by the debtor's assets' loss of going-concern value in a liquidation, which further decreases the amount available to satisfy unsecured creditors' claims. $^{68}$

64 See In re Alyucan Interstate Corp., 12 Bankr. 803, 808 n.11 (Bankr. D. Utah 1981). "Foreclosure may likewise pose regulatory complications. Banks and insurance companies are traditionally limited in the amount of illiquid assets . . . which they can carry at any given time in their portfolio." Id.

${ }_{\text {os }}$ See 11 U.S.C. § 507 (Supp. V 1981). See generally 3 CollieR, supra note 27, II 507.

${ }_{68} 11$ U.S.C. $\S 506(a)$ (Supp. V 1981). See generally 3 ColliER, supra note 27, โ 506.

${ }^{67} 11$ U.S.C. \& 726(b) (Supp. V 1981).

${ }^{68}$ At a forced liquidation sale, a debtor's assets may fetch far less than they would normally. In In re First Century Trust Co., 12 Bankr. 204, 205-06, 208 (Bankr. W.D. Tenn. 1981), a debtor sold four of its seven duplexes for $\$ 93,000$, accepting a promissory note for $\$ 82,000$. The debtor subsequently defaulted on the mortgages to which all seven duplexes were subject. The debtor filed a chapter 11 petition in the hope of averting an announced foreclosure sale, but the court allowed the sale to proceed. At the sale, the same company that had been willing to pay $\$ 93,000$ for four duplexes purchased all seven for $\$ 20,667.78$, thus obtaining all the duplexes for the price it had originally intended to pay for one. (The court later invalidated the sale.) See Comment, The Secured Creditor's Right to Full Liquidation in Corporate Reorganization, 42 U. CHI. L. REV. 510.

For a discussion of the problems inherent in a race to the courthouse, see Jackson, Bankruptcy, Non-Bankruptcy Entitlements, and the Creditors' Bargain, 91 YALE L.J. 857, 860-68 
Using "completely compensatory" as the standard of adequate protection may thus undermine the basic purposes of the automatic stay. The debtor is subject to a drain on its limited cash resources and a lack of cooperation from its creditors in formulating a workout of their claims. Far from enjoying a breathing spell, the debtor may find itself still gasping for air, its reorganization effort doomed from the start. The creditors, for their part, may be pushed into chaotic competition with one another in a race for adequate protection that could leave those who are last at the finish without any protection at all.

\section{E. The Misapplication of the "Completely Compensatory" Standard}

\section{The Doctrine}

Courts construing adequate protection under sections 361 and 362 of the Code ${ }^{6 \theta}$ to mean complete compensation have relied primarily on Mure?'s definition of the term as it was used in section $77 \mathrm{~B}(\mathrm{~b})(5)$ of the

(1982). Jackson argues that this race may best be avoided by providing secured creditors with completely compensatory adequate protection, either in the form of a market-rate loan or an immediate and full cash pay-out. Id. at 875. This argument is premised upon the assumption that administrative inefficiency, increased transaction costs, and a lower aggregate "pool of assets" will result if the secured creditors' nonbankruptcy (state law) entitlements are submerged in the reorganization process. Id. at 861. Suppose, for example, a debtor has a key asset that has a going concern value $(\$ 49,000)$ which is less than its present market value $(\$ 50,000)$. In such a situation, Jackson suggests "it would be sensible to sell the [key asset] for $\$ 50,000$ " because it would "increase the value of the debtor's estate by $\$ 1,000$." Id. at 876 . But if unsecured creditors are able to insure that the debtor continues to use the key asset, thereby lowering its value, and concomitantly the expected value of the secured creditor's claim against the key asset, the unsecured creditors will do so even if it means losing the additional $\$ 1,000$. In response, the secured creditors will either cause an increase in the cost of credit, engage in costly piecemeal bankruptcy litigation, or "engage in strategic behavior by, for example, realizing on the collateral earlier than would be collectively optimal, so as to "beat out' the unsecured creditors and foil their ability to do this." Id. at 876 (footnote omitted).

This analysis is flawed in several respects. First, the argument presupposes that aggregate monetary losses attributable to the reorganization process more than offset the process's monetary gains in the form of a reorganized business's post-petition profits. This presupposition may not be empirically accurate. See infra notes 76-86 and accompanying text. Second, and more specifically, unsecured creditors generally will wish to keep a business in operation only if it will generate future profits. If a business were to incur future losses, any unencumbered value available to discharge the unsecured creditors' claims would quickly evaporate. Also, because the "cram down" value of the secured creditor's secured claim can be determined at the outset of the reorganization proceedings, any loss of value in the secured asset will not decrease the amount of the secured creditor's claim against the assets of the debtor's estate. See generally infra notes 74-75 and accompanying text. Third, the argument presupposes, without empirical support, that decreased bankruptcy protection for a debtor's secured creditors will cause an increase in the cost of credit. See Jackson, supra, at 875 \& n.83. But see infra notes $76-80$ and accompanying text. Finally, if all secured creditors were to receive complete compensation for their nonbankruptcy entitlements, then all creditors might seek a secured position for their debts under the permissive procedures of the Uniform Commercial Code. See supra note 32 and accompanying text. In this scenario, providing complete compensation to each creditor either will be impossible, or will severely inhibit the debtor's ability to reorganize successfully.

68 11 U.S.C. $\S \S 361,362$ (Supp. V 1981); see supra notes $18 \& 27$ and accompanying text. 
Bankruptcy Act of $1898 .^{70}$ The uses of the term in the two statutes are not, however, interchangeable. Section 77B of the repealed Act required adequate protection in order to confirm the debtor's reorganization plan over the objection of a secured creditor. Section 362 of the current Code, in contrast, applies at a much earlier stage of the bankruptcy process: it requires adequate protection in the context of the automatic stay-a temporary, stop-gap measure designed merely to preserve the status quo between the filing of a bankruptcy petition and the ultimate confirmation of a reorganization plan. At the automatic-stay stage, creditors are to be protected from interim harm caused by the stay itself, not from harm caused by the debtor's underlying business failure. The standard of adequate protection applied under section 362, therefore, should not be as stringent as the standard applied in Murel. ${ }^{70.5}$

Another reason to reject the importation of the Murel definition into section 362 is that a shift has occurred in judicial interpretation of the takings clause. When section 77B was passed, courts construed the fifth amendment to bar any modification of secured creditors' rights. ${ }^{71}$ In light of modern readings of the takings clause, ${ }^{72}$ however, the new Bankruptcy Code presupposes that secured creditors' claims will be adjusted as a result of reorganization. ${ }^{78}$ This presupposition is reflected in the Code's "cram down" sections, which permit confirmation of a plan over the objections of one or more classes of creditors. ${ }^{74}$ Section 362 itself requires only that the debtor provide adequate protection of the creditors' secured "interest in property," which, under the Code, is equal to the amount of the debt or the value of the collateral, whichever is less. ${ }^{75}$ Thus, although legislative intent under the old Act may well

${ }^{70}$ Ch. $541, \S 77 \mathrm{~B}(\mathrm{~b})(5)$, as added by act of June 7, 1934, ch. 424, $\S 1,48$ Stat. 912 (1934) (codified as amended at 11 U.S.C. § 616(7) (1976) (repealed 1979)). See Murel, 75 F.2d at 942.

${ }^{70.8}$ See In re Pine Lake Village Apt. Co., 19 Bankr. 819, 827-28 (Bankr. S.D.N.Y. 1982); In re American Mariner Indus., Inc., 10 Bankr. 711, 712 (Bankr. C.D. Cal. 1981).

${ }^{71}$ Hand cautioned in Murel that "[i]n construing so vague a grant [as $\S 77 \mathrm{~B}$ ], we are to remember not only the underlying purposes of the section, but the constitutional limitations to which it must conform." 75 F.2d at 942. Opinions handed down shortly after Murel holding the impairment of a secured creditor's lien unconstitutional exemplify the judicial solicitude for property and, hence, creditors' rights typical of the time. See, e.g., Louisville Joint Stock Land Bank v. Radford, 295 U.S. 555, 560 (1935); Provident Mut. Life Ins. Co. v. University Evangelical Lutheran Church, 90 F.2d 992, 995 (9th Cir. 1937); Texas Hotel Sec. Corp. v. Waco Dev. Co., 87 F.2d 395, 400 (5th Cir. 1936); In re Tennessee Publishing Co., 81 F.2d 463, 468 (6th Cir. 1936), aff' on other grounds sub nom. Tennessee Publishing Co. v. American Nat'l Bank, 299 U.S. 18 (1936); see also infra text accompanying notes 93-129.

$7_{2}$ See infra text accompanying notes 130-64.

73 See 11 U.S.C. $\S \S 506,1129$ (Supp. V 1981) (determination of secured status; confirmation of plan).

7411 U.S.C. $\S 1129$ (b) (Supp. V 1981). The effect of $\S 1129$ is to decrease or "cram down" the secured creditor's claim from the full amount of the unpaid debt to the present value of the collateral securing the debt. See generally Klee, supra note 16.

${ }^{75}$ The Code gives a secured creditor the right to receive the present value of its allowed secured claim. 11 U.S.C. $\S 1129(\mathrm{~b})(2)(\mathrm{A})(\mathrm{i})(\mathrm{I})$ (Supp. V 1981). The allowed secured claim is 
have been to require complete compensation, the drafters of the new Code clearly believed that modification of secured creditors' claims was not only constitutionally permissible but, in some cases, desirable as well.

\section{Policies}

The purposes underlying the adequate protection requirement in the context of the automatic stay have been summarized by one bankruptcy judge thus:

In short, the adequate protection vouchsafed creditors in Chapter 11 is interim protection, designed not as a purgative of all creditor ailments, but as a palliative of the worst: reorganization, dismissal, or liquidation will provide the final relief. During this interim, the policies favoring rehabilitation and the benefits derived from the stay should not be lightly discarded. ${ }^{76}$

Courts that apply the completely compensatory standard appear to overlook these considerations, focusing instead on concerns other than debtor rehabilitation. They may fear, for example, that a more liberal standard of adequate protection will produce grave repercussions in the open credit economy. They may thus be concerned that any lesser protection of a creditor's security will pass on large losses to creditors, which will eventually reach other borrowers in the form of higher interest rates and decreased availability of credit. $^{{ }^{77}}$

Recent research indicates, however, that this "traditional theory" may not be supported by empirical data. It appears that lesser protection for creditors does not necessarily have a significant effect on the

limited to the amount of the debt or the value of the secured property, whichever is less. Id. $\S 506(\mathrm{a})$. The allowed secured claim is therefore the "interest in property" that must be adequately protected under the Code. See In re Alyucan Interstate Corp., 12 Bankr. 803, 808 \& n.10 (Bankr. D. Utah 1981); In re BBT, 11 Bankr. 224, 229 (Bankr. D. Nev. 1981); 124 CONG. REC. 32,395 (1978) (statement of Rep. Edwards) ("Adequate protection of an interest of an entity in property is intended to protect a creditor's allowed secured claim."); Gordanier, supra note 2, at 304.

Because the amount of the allowed secured claim is determined by the value of the collateral, valuation becomes a critical issue at the adequate protection hearing. The legislative history shows that Congress desired to leave valuation to the discretion of the court. See H.R. REP. No. 595, supra note 5, at 339, 1978 U.S. CODE CONG. \& AD. NEWS at 6295 . The choice between reorganization value or liquidation value, or of some value in between, is to be based upon the particular facts and equities of each case. Id. The tendency is, however, to give going-concern value. See 2 CoLliER, supra note 27, I 361.02. See generally Gordanier, supra, at 303-06; Webster, supra note 25, at 232; Comment, supra note 68 .

${ }^{70}$ In re Alyucan Interstate Corp., 12 Bankr. 803, 806 (Bankr. D. Utah 1981) (Mabey, J.).

77 See Gordanier, supra note 2, at 300, 327; Meckling, Financial Markets, Default, and Bankruptcy: The Role of the State, LAW \& CONTEMP. PROBS., Autumn 1977, at 13, 23; Comment, supra note 68 , at $526-27$. 
price or availability of credit. ${ }^{78}$ Interest rates and loan availability were found to remain substantially the same, regardless of whether states increase the number of exemptions available to a debtor under state law or allow debtors to waive their exemptions completely. ${ }^{79}$ Similarly, the Second Circuit's adoption of a very liberal attitude towards lien avoidance caused neither an increase in interest rates nor any decrease in credit availability. ${ }^{\mathbf{8 0}}$

The traditional theory also fails to take into account the "dismal alternative to [reorganization]-straight bankruptcy."81 According to the Brookings Institution, the average recovery on an allowed secured claim in a straight bankruptcy is thirty-one cents on the dollar. ${ }^{82}$ Thus the stay itself, even if it entirely depletes the value of the debtor's assets, causes only thirty-one percent of the creditor's loss. In addition, because the Internal Revenue Code taxes businesses at a rate of fifty percent, ${ }^{83}$ creditors incur a real loss of only half the diminution in the value of their collateral caused by the stay. Once these factors are taken into account, it appears that secured creditors would be risking only sixteen cents on the dollar if more liberal adequate protection standards were employed.

Finally, the traditonal theory ignores the "ripple effect" that liquidation of a local business often has on the community. ${ }^{84}$ The social and economic harm resulting from joblessness, a decreasing taxbase, in-

78 See Schuchman, Theory and Reality in Bankruptcy: The Spherical Chicken, LAW \& CONTEMP. PROBS., Autumn 1977, at 76-80. Another author has suggested that the supply function of credit is positively sloped and not perfectly elastic as the traditional theory holds. If the credit supply is positively sloped, a percentage of increased costs will not be shifted forward to consumers. Weston, Some Economic Fundamentals for an Analysis of Bankruptcy, id. at 47, 49-50; see also Miller, The Wealth Transfers of Bankruptcy: Some Illustrative Examples, id. at 39; Weistart, The Costs of Bankruptcy, id. at 107.

79 Schuchman, supra note 78, at 78-79. Exemptions enable a debtor to remove certain property, usually household, personal, and job-related property, from the estate. Once exempted from the debtor's estate, property cannot be reached by creditors to satisfy the debtor's debts. See 11 U.S.C. § 522(c), (d) (Supp. V 1981). Thus the number of exemptions allowed directly affects the amount a creditor can recover from a debtor's estate. In states that permit debtors to waive all exemptions, "virtually all consumer credit promissory notes contain such a provision." Schuchman, supra, at 79.

Bo Schuchman, supra note 78 , at $92-93$ \& n.101. Schuchman also notes that the absence of wage garnishment in several jurisdictions "seems to have made no cognizable difference in the availability and cost of consumer credit." Id. at 78-79 (footnote omitted).

B1 Webster, supra note 25 , at 202. "Straight bankruptcy" is the bankruptcy practitioner's vernacular for a liquidation proceeding under the bankruptcy laws. "Straight bankruptcy" proceedings are governed by 11 U.S.C. $\$ \S 701-766$ (Supp. V 1981).

${ }_{82}$ Webster, supra note 25, at 202 (citing D. STANLEY \& M. GirTh, BANKRUPTCY: ProbleM, PROCESS, REFORM 129 (1971)).

8s See I.R.C. $\S \S 165-166(1976)$. If a creditor's paper loss is $\$ 100$, it can deduct that amount from its gross income, thereby reducing its taxes by $\$ 50$. Bankruptcy courts should weigh this tax consideration in determining whether a creditor is adequately protected.

st Hard times on Main Street, TIME, Oct. 26, 1981, at 60, 61; see also Gordanier, supra note 2 , at $328,336$. 
creasing expenditures on entitlement programs for the unemployed, and the loss of business can often be severe. ${ }^{85}$ Indeed, if a lower standard of adequate protection enables some businesses to successfully reorganize rather than liquidate, both secured creditors and the public at large stand to gain from its adoption..$^{88}$

In sum, the definition of adequate protection as "completely compensatory" is neither mandated by the Code nor warranted by considerations of public policy. In its stead, bankruptcy courts should develop a concept of adequate protection that more equitably balances the interests favoring reorganization against the rights of secured creditors. Such a reformulation requires a thorough analysis of the considerations that shaped the concept of "adequate protection": the fifth amendment's prohibition against taking property without just compensation and the general contract-law principle that a party should not be deprived of the benefit of its bargain. ${ }^{87}$

\section{Defining Adequate Protection: An Alternative Standard}

A secured creditor's property and contractual interests may be seriously jeopardized by the imposition of an automatic stay under section 362 of the Code. ${ }^{88}$ In effect, the secured creditor that is unable to reclaim its collateral because of the stay is forced to give its property to the debtor, ${ }^{80}$ at least temporarily. In return, the secured creditor receives an allowed secured claim against the debtor's assets equal to the amount of the secured debt or the value of the secured asset on the date the bankruptcy petition was filed, whichever is less. ${ }^{90}$ The secured creditor thus has a legitimate concern; if the debtor's reorganization attempt proves unsuccessful and its assets substantially decrease in value, the unprotected secured creditor is unlikely to be compensated fully for its coerced loan.

The Code's requirement that the debtor provide adequate protec-

8s See Gordanier, supra note 2, at 336; TMME, supra note 84, at 60-61.

${ }^{88}$ See Rosenberg, supra note 2, at 510-11. 6295.

87 See H.R. REP. NO. 595, supra note 5, at 339, 1978 U.S. CODE CONG. \& AD. NEWS at

8811 U.S.C. $\S 362$ (Supp. V 1981).

80 The Code even requires that a creditor in possession of the collateral deliver it to the debtor or the trustee of the estate, unless the collateral is of inconsequential value to the estate or the creditor has obtained a court order permitting it to retain possession. 11 U.S.C. $\S 542(a)$ (Supp. V 1981). An order for delivery to the estate is typically referred to as a "turnover order." For a general discussion of the mechanics of the automatic stay, see Comment, Automatic Stay Under the 1978 Bankruptcy Code: An Equitable Roadblock to Secured Creditor Relief, 17 SAN DIEGO L. REV. 1113 (1980).

${ }^{90}$ See supra note 75 and accompanying text. 
tion of the secured creditor's interest in property ${ }^{91}$ was designed to guard creditors against this danger. To determine what "interest in property" is to be protected and what degree of protection is adequate, courts should look to the fifth amendment prohibition against taking property without just compensation and the contract-law principle that "[s]ecured creditors should not be deprived of the benefit of their bargain."92

\section{A. The Fifth Amendment Takings Clause and Adequate Protection}

Despite the recognized difficulties ${ }^{\text {9s }}$ in sifting through fifth amendment jurisprudence, it is critical that bankruptcy courts do just that in order to give proper content to the adequate protection requirement. The interpretation of the takings clause in the bankruptcy context began with Louisville Joint Stock Land Bank v. Radford ${ }^{94}$ and Wright v. Union Central Life Insurance Co. ${ }^{95}$ Both cases were cited in the legislative history of the present Bankruptcy Code as defining the fifth amendment's restraint on the bankruptcy power. ${ }^{96}$

91 11 U.S.C. $§ 362$ (Supp. V 1981).

${ }^{92}$ See S. REP. NO. 989, supra note 5, at 49, 53, 1978 U.S. CODE CONG. \& AD. NEWS at 5835, 5839; H.R. REP. No. 595, supra note 5, at 339, 1978 U.S. CODE CONG. \& AD. NEWS at 6295.

Commentators continue to debate whether secured creditors' rights should be left to judicial discretion or determined by clear rules of law. See 2 CoLLIER, supra note 27, II 362.01[3]; Baylor, After Bankruptcy Lets the Curtin Fall: Are Claims in Reorganization Proceedings for Post-Petition Interest at Higher "Default Rates" Consigned to Universal Darkness?", 86 CoM. L.J. 221, 230 (1981); Webster, supra note 25, at 198-200; Comment, supra note 89, at 1128 . One author has dubbed the courts' reliance on discretion to achieve desired results the "Doomsday Principle: The salutory and uncouth rule of law which proclaims necessity the mother of invention . . . " Fostersen, Equitable Powers in Bankruptcy Rehabilitation: Protection of the Debtor and the Doomsday Principle, 5 GREIGHTON L. REV. 221, 226 (1972), reprinted in 46 AM. BANKR. L.J. 311,317 (1972). Commentators advocating the need for clearer rules are concerned that the Doomsday Principle may harm secured creditors; when cold economic interests are balanced against very real human concerns, human concerns usually win out. This Comment does not advocate application of the Doomsday Principle in the context of the adequate protection hearing. Rather, the courts should exercise their inherent discretion within the confines of the underlying purposes of the adequate protection concept as outlined in this Comment.

9s The inquiry into what constitutes a "taking" under the fifth amendment has been termed " 'the most haunting jurisprudential problem in the field of contemporary land-use law . . . one that may be the lawyer's equivalent of the physicist's hunt for the quark.' "San Diego Gas \& Elec. Co. v. City of San Diego, 450 U.S. 621, 649 n.15 (1981) (Brennan, J., dissenting) (quoting C. HAAR, LAND-USE Planning 766 (3d ed. 1976)). But see Note, Reexamining the Supreme Court's View of the Taking Clause, 58 TEX. L. REV. 1447, 1447 (1980) (arguing that "[t]he constitutional problems presented by the taking clause, although difficult, do not deserve their present mystique").

9 295 U.S. 555 (1935).

os 311 U.S. 273 (1940).

os See supra note 92 . 


\section{Radford and Union Central}

The issue before the Supreme Court in Radford, and later in Union Central, was the constitutionality of two versions of the FrazierLemke Act, ${ }^{97}$ a piece of New Deal legislation amending the Bankruptcy Act of $1898 .{ }^{98}$ The original Frazier-Lemke Act, which was at issue in Radford, allowed financially distressed farmers unconditionally to stay secured creditors from foreclosing on encumbered farmland for five years. After the five-year period a farmer could buy the property, free from all liens, for its appraised value. Radford struck down the Frazier-Lemke Act as an unconstitutional taking of the secured creditor's property. ${ }^{98}$

The Court found that the Act constituted a taking of five substantive, state-created property rights. ${ }^{100}$ Because the Act applied exclusively to preexisting debts, ${ }^{101}$ the Radford Court derived these rights from the substantive rights the mortgagee had under preexisting state law. ${ }^{102}$ Under Kentucky law at the time, the mortgagee had the right to receive the full amount of the secured debt prior to releasing the lien. ${ }^{103}$ Under the Frazier-Lemke Act, the creditor was entitled only to the value of the collateral. ${ }^{104}$ The Court held that the mortgagee had vested property rights in the collateral, which the Frazier-Lemke Act abridged by impairing "the right of the mortgagee to obtain, through application of the security, payment of the indebtedness."105

Congress responded by amending the Frazier-Lemke Act. ${ }^{108}$ The only substantive change in the amended version, however, was that the

97 Act of June 28, 1934, ch. 869, 48 Stat. 1289, reenacted by Act of Aug. 28, 1935, ch. 792, 49 Stat. 942 (expired 1949) [hereinafter cited as Act of June 28, 1934].

${ }^{28}$ Ch. 541, 30 Stat. 544 (codified as amended at 11 U.S.C., in scattered sections of 28 U.S.C., and in scattered sections of other titles (1976) (repealed 1979)).

2925 U.S. at 601-02.

$100 \mathrm{Id}$. at 594. These five rights were:

1. The right to retain the lien until the indebtedness thereby secured is paid. 2 . The right to realize upon the security by a judicial public sale. 3 . The right to determine when such sale shall be held, subject only to the discretion of the court. 4 . The right to protect its interest in the property by bidding at such sale whenever held, and thus to assure having the mortgaged property devoted primarily to the satisfaction of the debt, either through receipt of the proceeds of a fair competitive sale or by taking the property itself. 5 . The right to control meanwhile the property during the period of default, subject only to the discretion of the court, and to have the rents and profits collected by a receiver for the satisfaction of the debt.

101 Act of June 28, 1934, supra note 97, $\S 75(\mathrm{a})(7)$.

102295 U.S. at 590.

108 "No provision [in the Kentucky law] permits the mortgagor to obtain a release or surrender of the property before foreclosure without paying in full the indebtedness secured." Id. at 59091.

104295 U.S. at 596-97.

105 Id. at 581, (citing Home Bldg. \& Loan Ass'n v. Blaisdell, 290 U.S. 398 (1934)).

108 Act of Aug. 28, 1935, ch. 792, 49 Stat. 942 (1935) (expired 1949). 
length of the stay was shortened from five years to three. ${ }^{107}$ Nevertheless, the Supreme Court upheld the amended statute in Wright v. Union Central Life Insurance Co. ${ }^{108}$ The Court premised its ruling on Wright v. Vinton Branch of the Mountain Trust Bank of Roanoke (Mountain Trust), ${ }^{109}$ which also upheld the constitutionality of the amended Frazier-Lemke Act. The Mountain Trust Court held that a three-year stay followed by an appraisal sale did not impair the secured creditor's state property rights so as to constitute a fifth amendment violation. ${ }^{110}$ The Court concluded that the scope of the fifth amendment's restraint on the bankruptcy power permitted the bankruptcy courts wide latitude in providing debtor relief:

A court of bankruptcy may affect the interests of lien holders in many ways. To carry out the purposes of the Bankruptcy Act, it may direct that . . the [collateral] be sold free of encumbrances and the rights of all lien holders be transferred to the proceeds of the sale. Despite the peremptory terms of a pledge, it may enjoin sale of the collateral, if it finds that the sale would hinder or delay preparation or consummation of a plan of reorganization. It may enjoin like action by a mortgagee whirh would defeat the purpose of [the Frazier-Lemke Act] to effect rehabilitation of the farmer mortgagor. ${ }^{111}$

In answering the secured creditor's constitutional attack in Union

107 Id. § 75(s)(3). See Rosenberg, supra note 2, at 522 n.45; Note, Constitutional Limitations on the Bankruptcy Power: Chapter XII Real Property Arrangements, 52 N.Y.U. L. REV. 362, 385-86 (1977). Later cases even extended the length of the stay beyond three years. See Wright v. Union Cent. Life Ins. Co., 304 U.S. 502, 515 (1938). The original version of the Frazier-Lemke Act had also provided for a judicial sale only when the debtor failed to pay the appraised value of the collateral. This provision was held unconstitutional because it eliminated the creditor's lien without repaying the full amount of the debt. Section $75(\mathrm{~s})(3)$ of the later version attempted to remedy this problem by allowing the creditor to request a judicial sale upon default and to bid in the full amount of the debt at the sale. After the sale, the debtor could redeem the property by paying the sale price, which was at least equal to the full amount of the debt. This modification protected the fourth enumerated Radford property right. See supra note 98.

This change seems, at first glance, to be substantial. In Union Central, however, the Court construed the revised version to allow the debtor to avoid a judicial sale by requesting an immediate appraisal upon default. The debtor could then redeem the property by paying only the appraised amount. 311 U.S. at $279-80$.

108311 U.S. 273 (1940).

109300 U.S. 440 (1937). Union Central actually cites John Hancock Mut. Life Ins. Co. v. Bartels, 308 U.S. 180 (1939) and Borchard v. California Bank, 310 U.S. 311 (1940), but these decisions are based on Mountain Trust's interpretation of the constitutionality of the FrazierLemke Act. See, e.g., Bartels, 308 U.S. at 187; Borchard, 310 U.S. at 316.

110300 U.S. at $458-70$.

111 Id. at 470 (citations omitted). 
Central, ${ }^{112}$ the Court adhered to its position in Mountain Trust, simply stating that "[s]afeguards were provided [in the amended FrazierLemke Act] to protect the rights of secured creditors . . . to the extent of the value of the property. There is no constitutional claim . . . to more than that."113

The Union Central Court's position that the fifth amendment protects only the secured creditor's right to receive the value of collateral is a complete reversal of the Radford Court, which rejected the same argument that was endorsed in Union Central. ${ }^{114}$ Yet nothing was added in the amended version that can account for this dramatic change in position. ${ }^{115}$ The shift may be attributable to the Supreme Court's abandonment of substantive due process as a standard for reviewing economic legislation. ${ }^{116}$

112311 U.S. 273 (1940).

113 Id. at 278 (citations omitted).

114 Compare Radford, 295 U.S. at 596 (no basis for assertion that the "only substantive right" of a creditor is "to have the value of the security applied to the satisfaction of the debt") with Union Central, 311 U.S. at 278 (the only constitutional claim a creditor can have is that its rights be protected "to the extent of the value of the property").

Actually, Radford appeared to have been overruled, albeit sub silentio, in Mountain Trust. See In re Ashe, 669 F.2d 105, 111 (3d Cir.), vacated and remanded in light of United States v. Security Indus. Bank, 103 S. Ct. 407 (1982), sub nom. Commonwealth Nat'l Bank v. Ashe, 103 S. Ct. 563 (1982) (mem.). Some authorities maintain, however, that Radford is still good law. See, e.g., Rodrock v. Security Indus. Bank, 642 F.2d 1193, 1198 (10th Cir. 1981) (subsequent cases and time "may well [have] refine[d] the rule of Radford, but they do not destroy the fundamental teaching of Radford that Congress may not under the bankruptcy power completely take for the benefit of a debtor rights in specific property previously acquired by a creditor") aff'd on other grounds sub nom. United States v. Security Indus. Bank, 103 S. Ct. 407, 410, 411 (1982) (citing Radiord without mentioning Union Central); Murphy, Restraint and Reimbursement: The Secured Creditor in Reorganization and Arrangement Proceedings, 30 BUs. LAW. 15, 26 (1974) ("No later opinion has substantially contradicted the basic holding of $R$ adford that a significant infringement of a substantive property right held by a secured creditor constitutes an uncompensated 'taking' . . . ."). But see In re Pillow, 8 Bankr. 404, 418 (Bankr. D. Utah 1981) ("[Radford] may, as one court suggests, stand 'as a venerable and vigorous sentinel of due process rights,' . . but it is a solitary sentinel standing at the watershed of a departed era in constitutional adjudication.") (quoting In re Rodrock, 3 Bankr. 629, 633 (Bankr. D. Colo. 1980)).

118 See supra notes 106-07 and accompanying text. The shift is all the more dramatic because Radford and Mountain Trust were both unanimous decisions, and both opinions were written by Justice Brandeis.

${ }_{116}$ See In re Ashe, 669 F.2d 105, 111 (3d Cir.), vacated and remanded mem. sub nom. Commonwealth Nat'l Bank v. Ashe, 103 S. Ct. 563 (1982); A. SUTHERLAND, CONSTITUTIONALiSM IN AMERICA 495 (1965) ("The opinions of the Supreme Court in the various cases which had gone counter to the New Deal in 1935 and 1936 had principally rested on two different constitutional theories, both limiting action by the national government; [one of which was based] on the Fifth Amendment Due Process Clause, construed to impose on the federal government a vague canon of economic traditionalism . . . .); Note, Constitutionality of Retroactive Lien Avoidance Under Bankruptcy Code Section 522(f), 94 HARV. L. ReV. 1616, 1629 n.87 (1981); Case Note, Bankruptcy-Section 522(f) of the 1978 Code-Constitutionality of Its Application to Security Interest Pre-Dating Enactment of the Code, 27 WAYNE L. REV. 1281, 1298 n.120 (1981). 


\section{a. The Union Central Rationale}

The Union Central Court implicitly adopted a balancing approach to the takings issue. ${ }^{117}$ Such an approach is reflected in the Court's statement that, in the reorganization context, the bankruptcy laws must be "liberally construed to give the debtor the full measure of relief afforded by Congress, lest its benefits be frittered away by narrow formalistic interpretations which disregard the spirit and letter of the . . . Act."118 Union Central does not, however, give much guidance concerning the definition of adequate protection under section 362 . The rights and interests balanced in Union Central are not the same as those that must be balanced today at the adequate protection hearing, when creditors seek removal of the automatic stay. Whereas the Frazier-Lemke Act at issue in Union Central was retroactive in its application, modifying property rights that existed before the passage of the Act, ${ }^{110}$ the rights affected by the automatic stay are defined by the Code itself. ${ }^{120}$

Still, Union Central does indicate that courts should adopt a flexible approach in adjudicating creditors' property rights. Although those rights remain significant, in the wake of Union Central they are no longer absolute and immutable. In protecting a secured creditor's property rights, courts must also accommodate the other concerns of the Bankruptcy Code, one of which is promoting successful debtor reorganization.

\section{b. The Prospective/Retroactive Distinction}

Property rights acquired anterior to the enactment of a law are generally treated differently from property rights that arise under existing law. This distinction rests on the notion that property rights exist only as a function of the law that creates them ${ }^{121}$ - that a property owner's rights are fixed by the law existing at the time the property was purchased. If enforcement of that law would have extinguished the property's value, its later enforcement should not constitute a taking because, under the law at the time of the purchase, the owner had no

117 Cf. Sax, Takings and the Police Power, 74 YALE L.J. 36, 61 (1964) (property rights are the "end result of a process of competition among inconsistent and contending economic values").

118 Union Central, 311 U.S. at 279 (citations omitted); see also Mountain Trust, 300 U.S. at 470 (emphasizing that the underlying purpose of the bankruptcy statute to allow debtor rehabilitation must be accorded controlling weight). But $c f$. In re Murel Holding Corp., 75 F.2d 941,942 (1935) (purpose of the statute is limited by constitutional requirement that adequate protection be "completely compensatory").

119 See supra note 101 and accompanying text.

120 See infra notes 121-27 and accompanying text.

121 See In re Carrol, 11 Bankr. 45, 47 (Bankr. E.D.N.Y. 1981). 
property right to take. ${ }^{122}$ If, on the other hand, a subsequent change in the law extinguishes preexisting property rights, the court should find a taking, for which the fifth amendment requires compensation. ${ }^{123}$

Secured creditors acquire only those rights in secured property that existing law, state and federal, grants them. Both Radford and Union Central involved the retroactive application of the FrazierLemke Act to preexisting state-created property rights-the five property rights enumerated in Radford. ${ }^{124}$ The automatic stay, however, is a prospective application of the bankruptcy law; the creditors' rights affected by an automatic stay are defined and limited by the Bankruptcy Code itself. Since 1940-the year Union Central was decided-federal law with regard to secured creditors' rights has been that the creditor is entitled to no more than the value of the property that secures its claim. ${ }^{125}$ This standard is essentially the same as that embodied in the Bankruptcy Code. ${ }^{126}$ Furthermore, federal bankruptcy law preempts state law purporting to grant secured creditors any greater rights in secured property. ${ }^{127}$

Thus, the secured creditor's property rights in collateral affected by the automatic stay are not the five state-created rights enumerated in

122 See id.; accord Flynn v. City of Cambridge, 1981 Mass. Adv. Sh. 692, 418 N.E.2d 335, 339-40 (holding that, although property owners had rights prior to enactment of new law, a deprivation of certain rights still may not constitute a taking; focus should be on character of action and nature and extent of interference) (citing Penn Central Transp. Co. v. New York City, 438 U.S. 104 (1978)); Kasparek v. Johnson County Bd. of Health, 288 N.W.2d 511, 518-19 (Iowa 1980) (en banc); National Advertising Co. v. State Highway Dep't, 230 Ga. 119, 122, 195 S.E.2d 895, 897 (1973); see also Note, supra note 116, at 1629-30.

125 See cases cited supra note 122; see also infra notes 130-64 and accompanying text; Note, supra note 116, at 1627-30. The prospective/retroactive distinction was the focus of controversy over the constitutionality of $\S 522(\mathfrak{1})(2)$ of the Code, permitting debtors to avoid certain liens that impair their exemptions. See supra note 79. Most, if not all, authorities agreed that extinguishment of $\S 522(f)(2)$ liens is permissible if the lien was created between the enactment of the Code and the date it became effective. See Case Note, supra note 116, at 1288 n.50 (listing cases). But courts and commentators were unable to reach a consensus on the constitutionality of $\S 522(f)(2)$ as applied to liens created before passage of the Code. In United States v. Security Indus. Bank, 103 S. Ct. 407 (1982), the Supreme Court resolved the $\S 522(f)(2)$ controversy, but not the constitutional issue. The Court held that the provision did not apply to preenactment liens because Congress did not clearly intend to apply the statute retroactively: "No bankruptcy law shall be construed to eliminate property rights which existed before the law was enacted in the absence of an explicit command from Congress." Id. at 414. But cf. id. at 414-16 (Blackmun, J., joined by Brennan \& Marshall, JJ., concurring) (reaching constitutional question and holding retroactive application of $\S 522(f)(2)$ a taking).

124 See supra note 98 . The original Frazier-Lemke Act, by its terms, applied only retroactively. Act of June 28,1934 , supra note $97, \S 75(\mathrm{~s})(7)$. The secured creditor in Union Central had acquired its security interest prior to the enactment of both the original and amended versions of the Frazier-Lemke Act. See Wright v. Union Cent. Life Ins. Co., 304 U.S. 502, 504 (1938) (mortgage executed Oct. 1, 1925).

123 See supra text accompanying note 113.

128 See supra note 75 and accompanying text.

127 See In re Carroll, 11 Bankr. 45, 47 (Bankr. E.D.N.Y. 1981). This is due to the conjunction of Congress's power to enact bankruptcy legislation, see U.S. CONST. art. I, $\$ 8, \mathrm{cl} .4$, and the supremacy clause, U.S. CONST. art. VI, cl. 2. 
Radford, but rather the rights granted the secured creditor under the Bankruptcy Code. A creditor's claim that its rights to foreclose and reinvest have been taken without just compensation by operation of the automatic stay is unfounded, for under federal law-the Bankruptcy Code-it was never granted those rights to begin with.

The secured creditor's right that must initially be thrown into the balancing process indicated in Union Central, ${ }^{128}$ therefore, is no more than what the Code provides: the right to the amount of the debt or the value of the secured property, whichever is less. ${ }^{129}$ Yet to grant a secured creditor the full amount of its debt or absolutely protect the value of its secured property would be to strike no balance at all. The question remaining, then, is how the balance should be struck. To what extent should the secured creditor's right yield to the debtor's right to attempt a successful reorganization? A survey of recent takings clause cases provides some guidance in this area.

\section{Takings-The Modern Era}

The Supreme Court's shift from striking down the Frazier-Lemke Act as unconstitutional in Radford to upholding the amended Act's constitutionality in Union Central reflects a broader shift in the law. Rather than defining property rights in rigid and static terms, modern jurisprudence views property rights as a fluid equilibrium accommodating competing interests. ${ }^{130}$ Bankruptcy courts should take account of this shift in adjudicating the rights of debtors and creditors.

The Supreme Court has not provided a bright-line test for determining whether a taking has occurred, ${ }_{2}^{131}$ viewing the question as essentially whether "the public at large, rather than a single owner, must bear the burden of an exercise of state power in the public interest."132 Translated into the setting of an adequate protection hearing, the question becomes who should bear the entrepreneurial risk of refinancing the debtor's business. In making this kind of determination, the Court has relied on three significant factors: (1) the character of the government action, (2) the extent of its economic impact, and (3) the degree of

128 See supra text accompanying note 117.

128 See supra note 75 and accompanying text.

1 so See Sax, supra note 117 , at 61 .

132 "[T]his court, quite simply, has been unable to develop any 'set formula' for determining when 'justice and fairness' require that economic injuries caused by public action be compensated by the government . . . ." Penn Cent. Transp. Co. v. New York City, 438 U.S. 104, 124 (1978); see also Dunham, Griggs v. Allegheny County in Perspective: Thirty Years of Supreme Court Expropriation Law, 1962 SUP. CT. REV. 63, 63 (describing a 30-year series of Court opinions resulting from this case-by-case approach as a "crazy-quilt pattern").

${ }^{192}$ Agins v. City of Tiburon, 447 U.S. 255, 260 (1980). 
its interference with reasonable investment-backed expectations. ${ }^{133}$ In addition, the Court sometimes relies on a fourth principle that looks to whether the affected parties enjoy an "average reciprocity of advantage."134

The second and third factors, the extent of the economic impact and the degree of interference with reasonable investment-backed expectations, are generally given less weight by the Court than the first. The extent of economic impact alone is rarely dispositive. The Court has permitted even a substantial diminution in the value of property affected by government action. ${ }^{135}$ For example, a zoning law that reduced the value of land from $\$ 800,000$ to $\$ 60,000$ was held not to be a taking. ${ }^{136}$ Similarly, a decrease in the value of a secured creditor's collateral before or during the imposition of an automatic stay under the Code should not be sufficient, absent other factors, to justify lifting the stay.

The third factor-the degree of interference with reasonable investment-backed expectations-is closely related to the extent of the action's economic impact. ${ }^{137}$ Although a commercial owner usually expects to put property to its most profitable use, the Supreme Court has ruled that such an expectation is not constitutionally protected. ${ }^{138}$ Government action that still allows "an economically viable use" for the property does not unreasonably interfere with the owner's investmentbacked expectations. ${ }^{139}$

1ss See Penn Cent. Transp. Co. v. New York City, 438 U.S. 104, 124 (1978); accord Loretto v. Teleprompter Manhattan CATV Corp., 102 S. Ct. 3164, 3171 (1982); PruneYard Shopping Center v. Robins, 447 U.S. 74, 83 (1980); see also Hodel v. Virginia Surface Mining \& Reclamation Ass'n, 452 U.S. 264 (1981) (citing Kaiser Aetna v. United States, 444 U.S. 164, 175 (1979)).

134 See infra notes 144-48 and accompanying text.

138 See Penn Cent. Transp. Co. v. New York City, 438 U.S. 104, 131 (1978). The diminution-in-value theory was originated by Justice Holmes in Pennsylvania Coal Co. v. Mahon, 260 U.S. 393 (1922): "The general rule at least is, that while property may be regulated to a certain extent, if regulation goes too far it will be recognized as a taking. . . This is a question of degree . . . ." Id. at 415-16. Recent commentators have concluded that Pennsylvania Coal's rationale has been overruled sub silentio. See, e.g., Note, Reexamining the Supreme Court's View of the Takings Clause, 48 TEX. L. REV. 1447, 1454-58 (1980). But cf. Loretto v. Teleprompter Manhattan CATV Corp., 102 S. Ct. 3164, 3171 (1982) ("The economic impact of the regulation, especially the degree of interference with investment-backed expectations, is of particular significance.").

${ }^{198}$ Hadacheck v. Sebastian, 239 U.S. 394 (1915); see also Euclid v. Ambler Realty Co., 272 U.S. 365 (1926) (75\% diminution not a taking); William C. Haas \& Co. v. City of San Francisco, 605 F.2d 1117 (9th Cir. 1979), cert. denied, 445 U.S. 928 (1980) (95\% diminution, from $\$ 2,000,000$ to $\$ 100,000$, not a taking).

1s7 See Penn Cent. Transp. Co. v. New York City, 438 U.S. 104, 135-36 (1978).

138 See Andrus v. Allard, 444 U.S. 51, 66 (1979) ("At any rate, loss of future profits-unaccompanied by any physical property restriction-provides a slender reed upon which to rest a takings claim.").

${ }^{139} I d$. There is, however, one apparent exception to the economically-viable-use standard. If government action deprives the property owner of a "fundamental right of ownership," Agins v. City of Tiburon, 447 U.S. 255, 262 (1980), the Court is more likely to characterize the action as a 
Andrus v. Allard ${ }^{140}$ provides a vivid example of the extent to which uncompensated government interference with commercial use of property for the public good is permissible. In Allard, the Court held that a dealer in Native-American artifacts containing bald eagle feathers was not deprived of his property ${ }^{141}$ by a federal law banning the sale of such feathers. ${ }^{142}$ The Court reasoned that the law still allowed the property owner an economically viable use for the feathers because the owner could exhibit the artifacts for an admission fee. ${ }^{143}$ Applying the rationale of Allard to the bankruptcy context, a creditor that has "invested" in the chapter 11 debtor is not constitutionally guaranteed the best return on that investment.

A further inquiry inherent in the Court's takings analysis, although not specifically identified, is whether the government's action "secured an average reciprocity of advantage"144 to the interests com-

taking. For example, in Kaiser Aetna v. United States, 444 U.S. 164 (1979), the government subjected a private waterway to its navigational servitude. The Court held that because the property owner's fundamental right to exclude others from its property was abridged, it was entitled to just compensation. Id. at 179-80.

Whether the "fundamental attribute of ownership" test is actually an exception to the threefactor test is doubtful. Compare Kaiser Aetna with Allard, in which the owner was deprived of the right to sell his property - certainly a fundamental attribute of ownership-but was held not to have been deprived of his property in violation of the fifth amendment. The Kaiser Aetna Court distinguished Allard as not involving a physical invasion of the owner's property. 444 U.S. at 180. Allard distinguished Pennsylvania Coal Co. v. Mahon, 260 U.S. 393 (1922), as involving a restriction on removal of property, resulting in loss of economic viability. 444 U.S. at $66, n .22$. See also PruneYard Shopping Center v. Robins, 447. U.S. 74, 82-84 (1980) (state's interference with owner's right to exclude not a taking). The "fundamental attribute of ownership" language used in Agins may be just a corollary to the "character of government action" factor. See supra text accompanying note 133; infra text accompanying notes 150-57.

160444 U.S. 51 (1979).

161 Id. at 67-68.

142 Eagle Protection and Migratory Bird Treaty Acts, 16 U.S.C. § 668(a) (Supp. III 1979) (amended 1979).

14s Allard, 444 U.S. at 66.

14260 U.S. at 415 . Like the diminution-in-value theory, see supra note 135 , the reciprocityof-advantage concept was originated in Holmes' opinion in Pennsylvania Coal Co. v. Mahon, 260 U.S. 393 (1922). Pennsylvania Coal held that a law that prohibited mining coal under residential property was an unconstitutional taking of the complaining miner's mineral rights under certain residential properties. Earlier, in Plymouth Coal Co. v. Pennsylvania, 232 U.S. 531 (1914), the Court had upheld a statute that required a coal miner to leave a pillar of coal along adjoining property lines as a safety barrier against flooding. Holmes distinguished Plymouth Coal on the ground that the statute in that case secured an "average reciprocity of advantage" between the two mining operations. Beause each miner was required to protect the other from flooding by leaving a pillar of coal unmined, each benefited from the imposition of the economic loss. Holmes ruled that the Pennsylvania Coal statute did not provide such a reciprocity of advantage because the miner did not benefit in any way from terminating its mining operations under residential property.

Although Pennsylvania Coal's diminution-in-value theory now appears to be obsolete, see supra note 135, the approach taken in Agins v. City of Tiburon, 447 U.S. 255 (1980), appears to have revived at least that portion of the Pennsylvania Coal rationale that approached the takings issue as a question of degree, balancing "the strong public desire to improve the public condition" against the private property owners' rights. 260 U.S. at 416 . Compare Agins, 447 U.S. at 260 ("The determination that governmental action constitutes a taking is, in essence, a determination that the public at large, rather than a single owner, must bear the burden of an exercise of state 
peting for the property's use. Such reciprocity can be found if the complaining party itself derives benefits from the imposition of the government action on other similarly situated property owners. The principle is illustrated by the case of Agins $v$. City of Tiburon, ${ }^{145}$ in which a property owner asserted that a local zoning ordinance restricting the number of dwellings he could build constituted a taking of his property. ${ }^{148}$ The Gourt held that there was no taking because, inter alia, "the zoning ordinances benefit[ted] the appellants as well as the public."147 Although the ordinances restricted the appellants' development rights, it also restricted those of their neighbors. This ensured that Tiburon's scenic beauty, which made property values there among the highest in California, would be maintained. ${ }^{148}$ Thus, the appellants received a reciprocal advantage-increased value of their land-from community-wide application of the restrictive zoning ordinances.

This argument might also be advanced in the bankruptcy context, although the relationship between restriction and advantage is somewhat more attenuated. It can be argued that, just as the Tiburon property owners benefitted collectively when prevented from fully exploiting their property rights individually, creditors as a class will ultimately benefit from a bankruptcy policy favoring debtor rehabilitation. Individually, creditors would probably prefer a policy allowing them to reclaim their collateral immediately, even if the effect is to force the debtor out of business. But rehabilitating debtors may well be better for the economy overall-particularly for the debtor's immediate community ${ }^{\mathbf{1 4 9}}$ - and therefore better for creditors as a whole.

The final, and perhaps the most decisive, factor in the takings analysis is the character of the government action. In a seminal article on the takings clause, ${ }^{150}$.Joseph Sax has suggested that courts should be more inclined to find a taking when private economic loss has been caused by the government acting in its role as enterprise-when, for example, the government has used private property to build a road or a power plant. ${ }^{161}$ When, on the other hand, the government acts only as

power in the public interest.") with Pennsylvania Coal, 260 U.S. at 416 ("But the question at bottom is upon whom the loss of the changes desired [to improve the public condition] should fall.")

14547 U.S. 255 (1980).

148 Id. at 258.

147 Id. at 262.

148 Id. "Appellants therefore will share with other owners the benefits and burdens of the city's exercise of its police power." Id. In Agins, the city was acting in its role as arbiter rather than in its role as enterprise, which also suggests that no taking should be found. See infra notes 150-54 and accompanying text.

119 See supra text accompanying notes 84-86.

180 Sax, supra note 117.

161 Id. at 62-63. 
arbiter or "mediator in the process of competition among competing economic claims,"162 Sax argues that it is much less likely to act arbitrarily or unfairly. ${ }^{153}$ Accordingly, Sax says, the government's denial of the use of property to one competing claimant in favor of another should generally be considered a "non-compensable exercise of the police power"154 rather than a taking.

The Supreme Court has adopted a similar approach, making the character of the government action a prime consideration in its threepart takings analysis. ${ }^{155}$ Like Sax, the Court has found a taking when the government appropriates property for its own use. ${ }^{166}$ In addition, the Court has held that the government's allowing a "physical invasion" of private property is, at least in some instances, a compensable taking. ${ }^{157}$

In imposing an automatic stay on secured creditors, the government is neither acting in its enterprise role nor authorizing a physical invasion of the creditors' property. Rather, acting as arbiter, the government is making a policy decison that secured creditors' claims to their collateral must be balanced against-and must sometimes yield to - the interests of debtors and of society as a whole in the successful reorganization of failing businesses.

Under the Court's three-part test, then, the character of the government's action in imposing an automatic stay appears to be unobjectionable. Any takings claim must therefore rely on the Court's other two factors: a near-extinguishment of the creditor's allowed secured

152 Id. at 62.

283 Id. at 64-67.

184 Id. at 63; see also Carruth v. United States, 627 F.2d 1068, 1081 (Ct. Cl. 1980).

155 See supra note 133 and accompanying text. Sax, however, reconsidered the efficacy of his enterprise/arbiter distinction and pointed out its failure to recognize that the roles are often inseparable-in assuming one, the government may inherently perform the other. Sax, Takings, Private Property and Public Rights, 81 YaLe L.J. 149 (1971). See generally Berger, A Policy Analysis of the Taking Problem, 49 N.Y.U. L. REV. 165 (1974) (examining the weaknesses of several historical approaches, including the enterprise/arbiter distinction). This critique came several years before the Court articulated the character of the government's action as a significant factor in takings analysis in Penn Central Transp. Co. v. New York City, 438 U.S. 104 (1978).

156 See, e.g., Kaiser Aetna v. United States, 444 U.S. 164 (1979) (government subjected private property to its navigational servitude); Armstrong v. United States, 364 U.S. 40 (1960) (government's action destroyed the value of petitioner's liens).

${ }^{167}$ More recently, the Court has relied on a distinction between physical invasions that are permanent and those that are temporary. Compare Loretto v. Teleprompter Manhattan CATV Corp., 102 S. Ct. 3164, 3178 (1982) (statute allowing cable television firm to install device on building for only nominal fee a taking of landlord's property because "invasion" permanent) with PruneYard Shopping Center v. Robins, 447 U.S. 74, 84 (1980) (state's allowing distribution of leaflets in private shopping center not a taking because owner's "right to exclude others" not "essential to the use or economic value of [the] property"). See also Loretto, 102 S. Ct. at 3174 n.9 (rejecting distinction between takings by government itself and government-authorized takings by private parties). Loretto provides little guidance in defining adequate protection because the automatic stay is of temporary duration. 
claim, or a substantial interference with its reasonable investmentbacked expectations. ${ }^{188}$

In determining the reasonableness of creditors' investment-backed expectations, courts should consider the terms of the security instrument and the circumstances of its acquisition. For instance, a creditor that bought the debtor's obligation at a discount while the debtor was in financial difficulties should receive less protection than a secured creditor that extended credit directly to a financially troubled business. ${ }^{159}$ If a secured creditor extended credit to purchase an asset only on the condition that a substantial equity cushion be maintained, it should receive relatively more protection than a trade creditor that did not investigate the debtor's finances and did not bargain for an equity cushion.

Any calculation of the economic harm caused by the imposition of an automatic stay should also take into account the tax benefits a creditor can secure by claiming a bankruptcy related loss on its tax return. ${ }^{160}$ Going beyond benefits that might accrue to an individual creditor, courts might introduce the principle of average reciprocity of advantage into their adequate protection rulings. ${ }^{161}$ Courts should, under this approach, consider the overall benefits that the economic community, including other creditors, may realize if the debtor is allowed time to attempt a reorganization.

Thus, barring a substantial likelihood that the assets securing a creditor's claim will become almost worthless during the pendency of the automatic stay, ${ }^{\mathbf{1 6 2}}$ bankruptcy courts are not constitutionally re-

158 See supra text accompanying notes 135-43.

189 See Allard, 444 U.S. 51, 64-65 n.21 (1979). ("The timing of acquisition of the property is relevant to a takings analysis of [the claimants'] investment-backed expectations . . . ."); see also In re Gaslight Village, Inc., 8 Bankr. 866, 871 (Bankr. D. Conn. 1981) (citing In re Tucker, 5 Bankr. 180 (Bankr. S.D.N.Y. 1980)) ("[A]n assignee of a claim who enters upon the scene with eyes wide open and is knowledgeable as to the debtor's then financial condition should be accorded a lesser degree of protection than the assignor who originally structured the transaction with higher expectations."). Other examples of relevant considerations may include whether the creditor has bad-debt insurance; whether the creditor can claim a bad-debt loss on its federal tax return; or whether the creditor has been diligent in protecting its encumbrance.

${ }_{180}$ See supra note 83.

161 See supra text accompanying notes 144-49.

${ }^{162}$ In a footnote to its opinion in Agins, the Supreme Court noted that "[m]ere fuctuations in value during the process of governmental decisionmaking, absent extraordinary delay, are incidents of ownership. They cannot be considered as a "taking" in the constitutional sense." 447 U.S. at 263 n.9 (quoting Danforth v. United States, 308 U.S. 271, 285 (1939)). The undersecured creditor thus has no right to compensation in the form of postpetition interest for the delay the government caused by the stay. In re Pine Lake Village Apt. Co., 19 Bankr. 819, 828 (Bankr. S.D.N.Y. 1982); see also Allard, 444 U.S. at 66 (loss of future profit not compensable taking); New Haven Inclusion Cases, 399 U.S. 392, 491 (1970) ("We do not doubt that the time consumed in the course of the proceedings in the reorganization court has imposed a substantial loss upon the bondholders. But . . . we see no constitutional bar to that result."); Continental Ill. Nat'l Bank \& Trust Co. v. Chicago R.I. \& P. Ry., 294 U.S. 648, 677-78 (1935). But see In re 
quired to lift it: "indubitable equivalence" in the sense of complete compensation ${ }^{163}$ is not required to provide secured creditors with adequate protection under section 362 of the Code. Modern fifth amendment jurisprudence may be used to argue instead for a flexible approach to property rights, one that allows the court to consider interests other than those of the creditor in deciding whether adequate protection has been provided.

The analysis, however, must go beyond the fifth amendment. The legislative history of the Bankruptcy Code indicates that the adequate protection requirement was designed not only to meet the requirements of the takings clause but also to provide the creditor with limited assurance that it will obtain the benefit of its bargain. ${ }^{\mathbf{1 0 4}}$

\section{B. The Benefit of the Bargain}

A recurring theme in the cases using the "completely compensatory" standard of adequate protection is that a secured creditor must be assured of receiving the full benefit of its bargain with the debtor. ${ }^{105}$ The House and Senate reports on the Bankruptcy Code declare that "the concept of adequate protection [is] based as much on policy grounds as on constitutional grounds. Secured creditors should not be deprived of the benefit of their bargain."188

Congress apparently intended, however, that the secured creditor's bargain would sometimes yield to the debtor's reasonable reorganization efforts. The House and Senate reports also observe that " $[t]$ here may be situations in bankruptcy where giving a secured creditor an absolute right to his bargain may be impossible or seriously detrimental to the bankruptcy laws. Thus, [section 361] recognizes the availability of alternative means of protecting a secured creditor's interest."

Heath, 9 Bankr. 665, 668-69 (Bankr. E.D. Pa. 1981).

There is no need for the creditor to endure unreasonable delay. If the debtor is using the stay as a subterfuge for delay, the creditor can seek to lift the stay for cause. See, e.g., In re Tucker, 5 Bankr. 180, 184 (Bankr. S.D.N.Y. 1980). If the creditor is truly troubled by delay, it can file its own plan for the debtor's reorganization under 11 U.S.C. § 1121 (c) (Supp. V 1981) (creditor may file plan if "the debtor has not filed a plan before 120 days after the date of the order for relief under this Chapter"), or convert the reorganization into a liquidation proceeding under 11 U.S.C. $\S 1112$ (b)(4) (Supp. V 1981) (only done for cause, which includes failure to propose a plan). See In re American Mariner Indus., Inc., 10 Bankr. 711, 713 (Bankr. C.D. Cal. 1981) (if time period becomes unreasonable, creditor may convert to liquidation procedure under $\S 1112(b)(4))$.

163 See supra text accompanying notes 39-43.

${ }^{104}$ See supra text accompanying notes 20-22.

168 See, e.g., In re Tucker, 5 Bankr. 180, 183 (Bankr. S.D.N.Y. 1980); In re Kenny Kar Leasing, Inc., 5 Bankr. 304 (Bankr. C.D. Cal. 1980); In re Paradise Boat Leasing Corp., 2 Bankr. 482, 483-84 (Bankr. D. St. Thomas \& St. John, V.I. 1979).

${ }^{188}$ See supra note 20.

167 See id.; In re Kenny Kar Leasing, Inc., 5 Bankr. 304, 308-09 (Bankr. C.D. Cal. 1980) (urging a balancing approach to accommodating the rights of secured creditors and debtors); see 
statement indicates that all that a secured creditor can expect from its bargain, if the other party goes bankrupt, is a fair and equitable accommodation between its rights and the debtor's rights under the Code. ${ }^{168}$ The benefit-of-the-bargain policy may therefore be nothing more than a restatement of the old doctrine that every contract incorporates the existing bankruptcy laws into its terms. ${ }^{109}$

If so, the terms of the secured creditor's bargain include the restrictions the Gode places on the creditor's ability to collect its debt. ${ }^{170}$ These restrictions are found in the standard necessary to confirm a reorganization plan over secured creditor's objections. ${ }^{171}$ At this final disposition of secured creditors' property, the "cram down," the Code entitles the creditor to no more than the present value of its allowed secured claim. ${ }^{172}$ As the congressional reports state, the benefit-of-thebargain policy represents only the general goal that the debtor should be made to pay its creditors as much as it is able to without seriously impairing the debtor's chances for successful reorganization. ${ }^{173}$

In the automatic-stay context, adequate protection for creditors should mean no more than is required by the confirmation standards, and in most cases it should mean less. As a practical matter, requiring complete compensation at the automatic-stay stage would render the cram-down standards unnecessary. If adequate protection is read to require complete compensation of the original bargain, which may be much more than the present value of the claim, secured creditors will have strong incentives to circumvent cram down by requesting adequate protection hearings. The increased requests for adequate protection generated by this approach will place added burdens on the debtor's resources and further detract from the creditor's disposition to negotiate a voluntary plan with the debtor.

also In re Mickler, 9 Bankr. 121 (Bankr. M.D. Fla. 1981); In re Family Invs., Inc., 8 Bankr. 572 , 576 (Bankr. W.D. Ky. 1981); In re Hutton-Johnson Co., 6 Bankr. 855, 860 (Bankr. S.D.N.Y. 1980) ("It should be observed, however, that it does not follow that the concept of adequate protection is designed to put the secured creditor in the same position it was in when it initially negotiated the transaction."); In re San Clemente Estates, 5 Bankr. 605, 611 (Bankr. S.D. Cal. 1980) (public policy protecting integrity of bank outweighed by public policy favoring debtor reorganization).

16s See Comment, supra note 89, at 1123; supra notes 130-62 and accompanying text; $c$. Jackson, supra note 68 , at 860 .

16* See Hanover Nat'l Bank v. Moyses, 186 U.S. 181, 189 (1902); see also Wright v. Union Cent. Life Ins. Co., 304 U.S. 503, 505-18 (1938); Home Bldg. \& Loan Ass'n v. Blaisdell, 290 U.S. 398, 435 (1934); 2 CoLLIER, supra note 27, at I 362.01[1]; Gordanier, supra note 2, at 305. 170 See New Haven Inclusion Cases, 399 U.S. 392, 491 (1970); In re BBT, 11 Bankr. 224, 236 (Bankr. D. Nev. 1981) (the creditor's bargain is that it is entitled to payment subject to the provisions of the Bankruptcy Code); In re Mickler, 9 Bankr. 121, 123 (Bankr. M.D. Fla. 1981); In re Family Invs., Inc., 8 Bankr. 572, 576 (Bankr. W.D. Ky. 1981).

17111 U.S.C. \& 1129 (Supp. V 1981).

173 Id. \& $1129(\mathrm{~b})(2)(\mathrm{a})$.

173 See supra note 167 and accompanying text. 
Because adequate protection was designed as an interim arrangement and not as the final measure of creditor relief, ${ }^{174}$ it should be set at a level that guards only against significant impairment of the secured status of a creditor's claim that may be caused by the stay. Unless the stay is likely to render the collateral worthless, the amount of adequate protection required by the Code may fall far short of the present value of the allowed secured claim. That amount, which is the benefit of the creditor's bargain, is guaranteed by the confirmation standards. The adequate protection requirement serves only to protect, not insure, the secured creditor's ability to receive that benefit from the value of the collateral should the debtor fail to have a reorganization plan confirmed.

\section{CONCLUSION}

Not all businesses that file for reorganization should be rescued. Financial difficulties that go beyond temporary setbacks in the market or cash-flow problems may be solved best by liquidating the business. Once the court has found that effective reorganization is possible, ${ }^{175}$ however, the debtor should be given ' a reasonable opportunity to retain and exploit the assets it needs to formulate a successful reorganization plan. The requirement that the debtor provide its secured creditors with adequate protection should not be interpreted so as to defeat the debtor's reorganization efforts. A number of courts have relied on just such an interpretation, reading "adequate protection" to mean "complete compensation" rather than merely interim protection of the present value of secured creditor's collateral.

Neither the constitutional nor the policy restraints on debtor relief embodied in the concept of adequate protection require that the creditor's compensation be complete. Case law and the fundamental policy of the Code's reorganization provisions justify the bankruptcy courts' consideration of interests favoring debtor reorganization that go beyond the immediate parties: the interests of the debtor's employees, the government treasury, the debtor's suppliers, and the debtor's unsecured creditors. As long as substantial diminution of the value of the collateral appears unlikely, the bankruptcy court is free to balance these interests as the equities of the particular case dictate.

In doing so, the court should be guided by present-day interpretations of the fifth amendment takings clause and by the statutory policy of allowing creditors the benefit of their bargain. These two considera- 
tions, which were uppermost in Congress's collective mind when it drafted section 362 of the Code, indicate first, that creditors' property rights are not immutable; second, that the benefit of a secured creditor's bargain is limited to the amount of the debt it is owed or the value of the collateral, whichever is less; and third, that a secured creditor's property rights and the benefit of its bargain may at times be subordinated to the debtor's interest in successful reorganization. At the automatic-stay stage, when debtors' chances for rehabilitation may be so easily thwarted, courts should strive for results that fulfill the basic role of reorganization as a "process [that] presupposes dynamic rather than static uses of property and denouement in a plan which accommodates the many, not just the few,"176 
. 